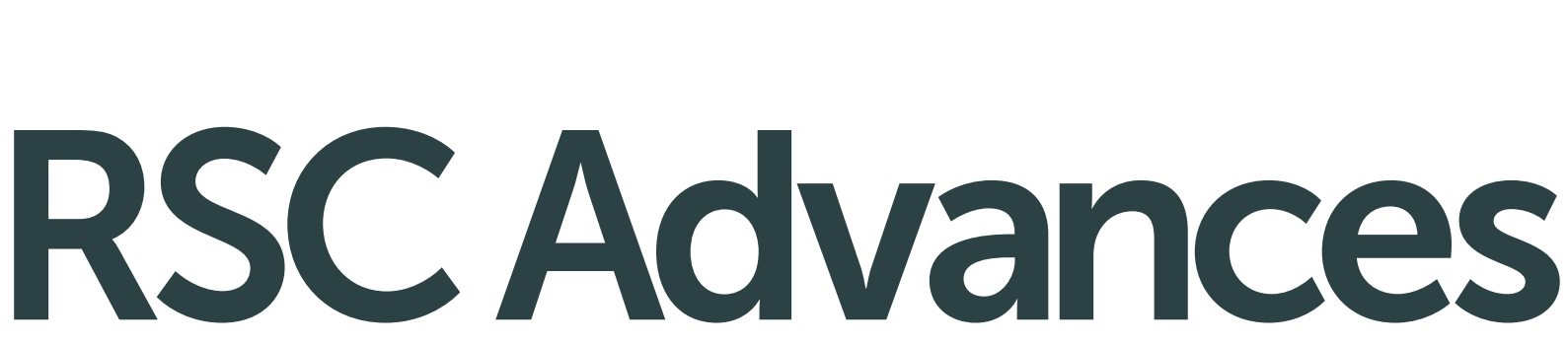

This article can be cited before page numbers have been issued, to do this please use: M. L. Godino, M.

D. Gutierrez, R. Lopez, P. Arranz, A. Santiago-Medina, M. Melguizo, M. Domingo-Garcia, F. J. Lopez-

Garzon, V. K. Abdelkader Fernandez, C. Salinas and M. C. Román-Martínez, RSC Adv., 2016, DOI:
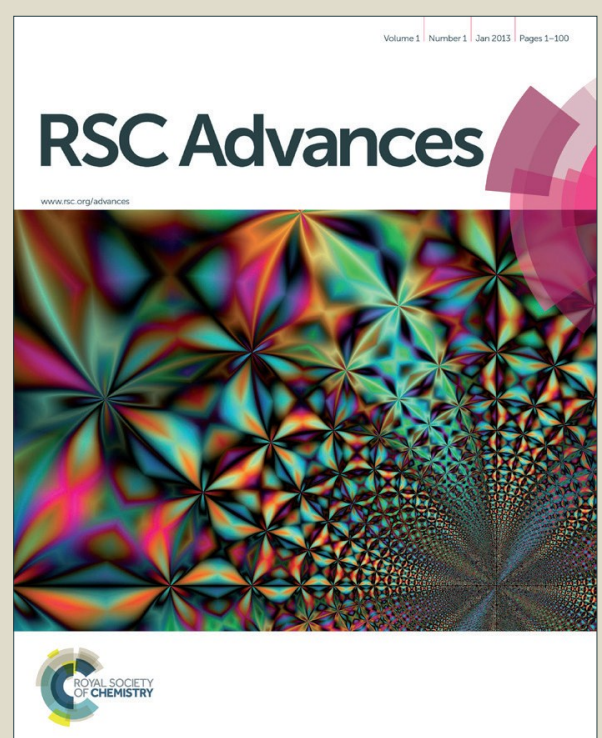

This is an Accepted Manuscript, which has been through the Royal Society of Chemistry peer review process and has been accepted for publication.

Accepted Manuscripts are published online shortly after acceptance, before technical editing, formatting and proof reading. Using this free service, authors can make their results available to the community, in citable form, before we publish the edited article. This Accepted Manuscript will be replaced by the edited, formatted and paginated article as soon as this is available.

You can find more information about Accepted Manuscripts in the Information for Authors.

Please note that technical editing may introduce minor changes to the text and/or graphics, which may alter content. The journal's standard Terms \& Conditions and the Ethical guidelines still apply. In no event shall the Royal Society of Chemistry be held responsible for any errors or omissions in this Accepted Manuscript or any consequences arising from the use of any information it contains. 


\title{
New hybrid materials based on the grafting of Pd(II)-amino complexes on the graphitic surface of AC: Preparation, structures and catalytic properties
}

\author{
M. Luz Godino-Salido, ${ }^{\mathrm{a},{ }^{*}}$ María D. Gutiérrez-Valero, ${ }^{\mathrm{a}}$ Rafael López-Garzón, ${ }^{\mathrm{a}}$ Paloma \\ Arranz-Mascarós, ${ }^{\mathrm{a}}$ Antonio Santiago-Medina, ${ }^{\mathrm{a}}$ Manuel Melguizo, ${ }^{\mathrm{a}}$ María Domingo- \\ García, ${ }^{b}$ F. Javier López-Garzón, ${ }^{b}$ Victor K. Abdelkader-Fernández, Concepción \\ Salinas-Martínez de Lecea, ${ }^{\mathrm{c}}$ M. Carmen Román-Martínez ${ }^{\mathrm{c}}$
}

${ }^{a}$ Departamento de Química Inorgánica y Orgánica. Facultad de Ciencias Experimentales. Universidad de Jaén, 23071, Jaén, Spain.

${ }^{\mathrm{b}}$ Departamento de Química Inorgánica. Facultad de Ciencias. Universidad de Granada, 18071, Granada, Spain.

${ }^{\mathrm{c}}$ Departamento de Química Inorgánica. Universidad de Alicante, Ap. 99, Alicante, Spain.

\begin{abstract}
A novel procedure for the preparation of solid Pd(II)-based catalysts consisting in the anchorage of designed $\mathrm{Pd}(\mathrm{II})$-complexes on activated carbon (AC) surface is reported. Two molecules of Ar-S-F type (where Ar is a plane-pyrimidine moiety, F a $\operatorname{Pd}(\mathrm{II})$ ligand and $\mathrm{S}$ an aliphatic linker) differing in $\mathrm{F}$, were grafted on an $\mathrm{AC}$ by $\pi-\pi$ stacking of Ar moiety and the graphene planes of $\mathrm{AC}$, thus favouring the retaining of the metalcomplexing ability of $\mathrm{F}$. Adsorption of $\mathrm{Pd}(\mathrm{II})$ by the $\mathrm{AC} / \mathrm{Ar}-\mathrm{S}-\mathrm{F}$ hybrids occurs via $\mathrm{Pd}(\mathrm{II})$-complexation by F. After deep characterization, the catalytic activities of AC/Ar-
\end{abstract}

\footnotetext{
* Corresponding author. Tel: +34 953212745; Fax: +34 953211876

E-mail address: mlgodino@ujaen.es (M. Luz Godino-Salido)
} 
$\mathrm{S}-\mathrm{F} / \mathrm{Pd}(\mathrm{II})$ hybrids on the hydrogenation of 1-octene in methanol as a catalytic test were evaluated. $100 \%$ conversion to $\mathrm{n}$-octane at $\mathrm{T}=323.1 \mathrm{~K}$ and $\mathrm{P}=15 \mathrm{bar}$, was obtained with both catalysts and most of $\operatorname{Pd}(\mathrm{II})$ was reduced to $\operatorname{Pd}(0)$ nanoparticles, which remained on the AC surface. Reusing of the catalysts in three additional cycles reveals that the catalyst bearing the F ligand with larger Pd-complexing ability showed no loss of activity (100\% conversion to n-octane) which is assigned to its larger structural stability. The catalyst with the weaker $\mathrm{F}$ ligand underwent progressive loss of activity (from $100 \%$ to $79 \%$ in four cycles), due to the constant aggregation of the $\operatorname{Pd}(0)$ nanoparticles. Milder conditions, $\mathrm{T}=303.1 \mathrm{~K}$ and $\mathrm{P}=1.5 \mathrm{bar}$, prevent the aggregation of the $\operatorname{Pd}(0)$ nanoparticles in this catalyst allowing the retaining of high catalytic efficiency (100\% conversion) in four reaction cycles.

\section{Introduction}

It is known that the interest in heterogeneous catalysis partially comes from the possibility of an easier and more complete recovery of the catalyst (which often implies low contamination of the reaction medium) than in homogeneous catalysis. Functionalized carbon materials, including activated carbons (ACs), carbon nanotubes (NTs) and graphene (G), and other materials such as zeolites and silica gels, are used as solid materials having both catalytic and adsorbent properties. ${ }^{1-7}$ Nevertheless, ACs are accessible and low-cost materials as they are obtained not only from different natural sources, but also from waste materials (which are so converted into added value products). ${ }^{2-10}$ Thus, ACs are extensively used as solid supports in heterogeneous catalysis due to their high surface areas, chemical stabilities and high adsorptivities are very important features for this purpose. The suitable control of the catalyst preparation from ACs is a crucial issue to reach large efficiency. Thus, the aim is to have catalysts with suitable amounts of surface-active sites and a highly homogeneous distribution of them.

We have reported that the adsorption of molecules of Ar-S-F type (Scheme 1) on ACs under controlled conditions results in their homogeneous distribution on the surface due to $\pi-\pi$ interactions between the pyrimidine residue, Ar of Ar-S-F, and the arene centers $(\mathrm{C} \pi)$ of the graphene surface (Scheme 1). ${ }^{11-13}$ Moreover if the majority of the Ar-S-F molecules are adsorbed into open pores (meso- and macropores) the strong $\pi-\pi$ interactions give rise to stable $\mathrm{AC} / \mathrm{Ar}-\mathrm{S}-\mathrm{F}$ hybrid materials. In these hybrids the 
functional groups conjugated with the pyrimidine (plane) residue are blocked (due to the plane to plane interaction) whilst, should the character of S-F residues are non-aromatic, the properties of $\mathrm{F}$ (free) functions are efficiently transferred to the AC surface. Should the Ar-S-F molecules adsorb on narrow pores the functions $\mathrm{F}$ are submitted to stereochemical restrictions which block the F properties. ${ }^{14}$ Thus, once the Ar-S-F molecules are adsorbed into open pores the subsequent adsorption of metal ions by the hybrid materials AC/Ar-S-F is mainly controlled via complexation of the metal ion by the $\mathrm{F}$ function (Scheme 1). ${ }^{12,13,15-17}$ This provides a suitable strategy to prepare solid catalysts based on the catalytic properties of metal-ion complexes supported on the graphene surface of the AC. This method catalyst preparation has two important advantages: i) it allows the exhaustive control of the amount of active sites on the surface of the hybrid material and ii) the textural and chemical functions of the starting $\mathrm{AC}$ remain unaltered in the hybrid due to the soft conditions of preparation.
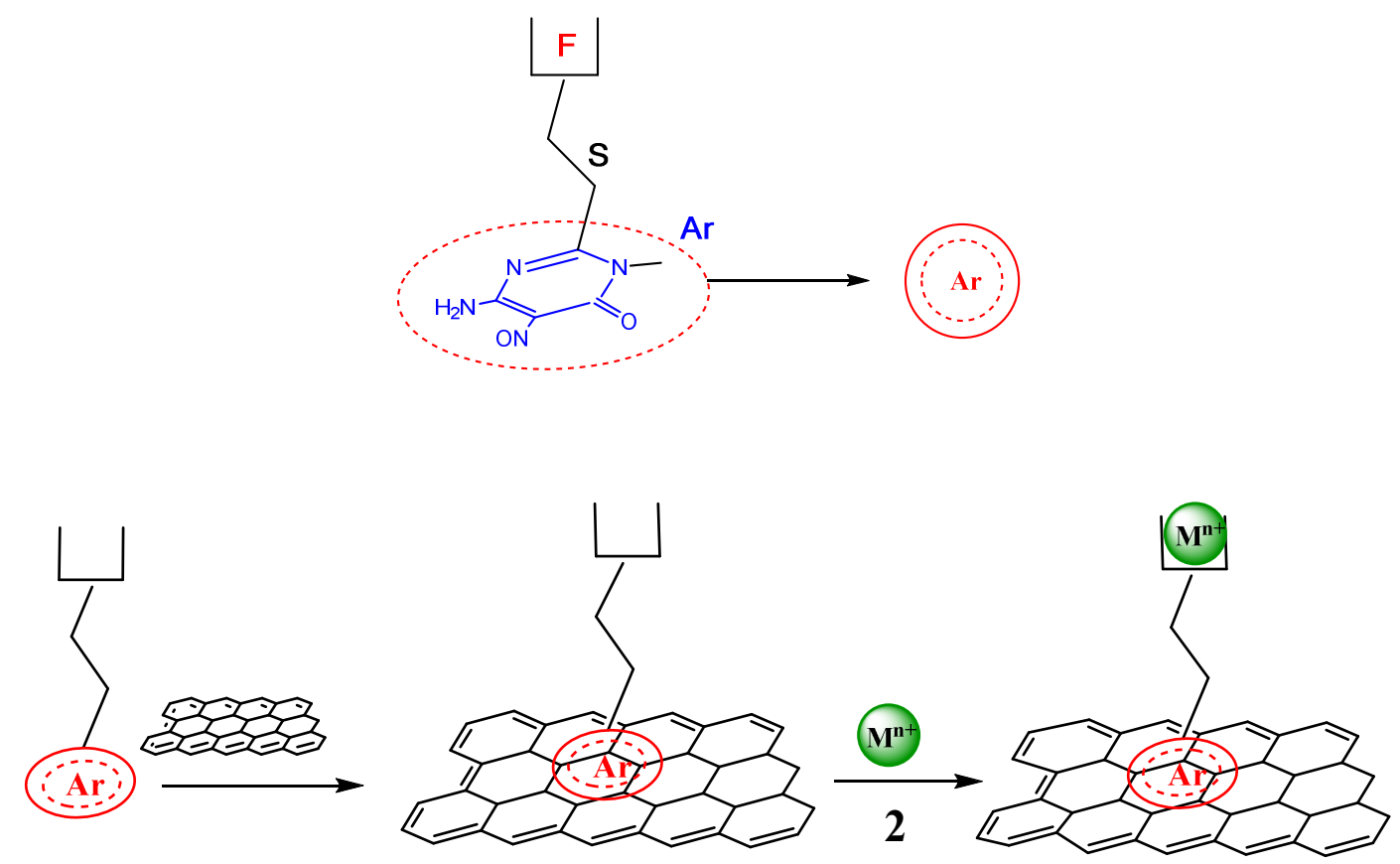

Scheme 1. At the top, the structure of a molecular receptor of the Ar-S-F type. At the bottom the schematic representation of the attachment of Ar-S-F to a graphene sheet of an AC (step 1) and the attachment of a metal ion to the Ar-S-F hybrid via complexation with F function (step 2). 
Palladium (II) complexes have been extensively used as catalysts ${ }^{18,19}$ in homogeneous phase in reactions such as the $\mathrm{CO}_{2}$ hydrogenation to obtain methanol, ${ }^{20}$ the preparation of biodiesel, ${ }^{21}$ the cross coupling reactions in organic synthesis ${ }^{22,23}$ and the hydrogenation of alkenes. ${ }^{24-31}$ These last reactions are widely used in processes such as in the hydrogenation of petroleum cracking byproducts and in the fatty acid hydrogenation. ${ }^{28-30}$ The main drawback of using Pd(II) catalysts is their high cost, but this can be overcome by optimizing both the efficiency of the catalytic processes and the reusability of the catalysts. Thus, designing efficient and easily recoverable $\mathrm{Pd}(\mathrm{II})$ catalysts in solid phase is an important issue, in particular for the reactions of hydrogenation of alkenes, for which the literature is scarce. ${ }^{32-37}$

$\mathrm{Pd}(\mathrm{II})$-amino acids complexes supported on polymeric resins have been prepared and used as catalysts for the hydrogenation of olefins. ${ }^{38}$ Similarly, $\operatorname{Pd}(\mathrm{II})$-amino complexes supported on zeolites have been used for the partial hydrogenation of 1,3ciclooctadiene. Moreover, Pd(II)-amino complexes supported on activated carbons have been also used as solid catalysts in hydrogenation reactions. ${ }^{36,39-41}$

The aim of this work is to obtain $\mathrm{AC} / \mathrm{Ar}-\mathrm{S}-\mathrm{F} / \mathrm{Pd}(\mathrm{II})$ hybrid materials with high catalytic efficiencies. Moreover, the aim is also to show that these efficiencies depend on: i) the suitable control of both the chemical nature and the amount of catalytic active sites (i.e., the surface-attached complex), and ii) the homogeneous distribution of the functions on the surface of the catalyst. Our results show that these requirements are reached provided the above described methodology (Scheme 1) is used for the preparation of the catalysts. Thus, two AC-based hybrids derived from two ligands of the Ar-S-F type (Scheme I), namely N-2-(4-amino-1,6-dihydro-1-methyl-5-nitroso-6-oxopyrimidinyl)L-lysine (Lys hereinafter, c.f. Scheme 2), and N-2-(4-amino-1,6-dihydro-1-methyl-5nitroso-6-oxopyrimidinyl)-tris-(2-aminoethyl)amine (Tren, Scheme 2) have been obtained. These two hybrids are labeled as Merck/Lys and Merck/Tren, respectively. They have been used to prepare the catalysts Merck/Lys-Pd and Merck/Tren-Pd by complexation of Lys and Tren molecules of the hybrids with $\operatorname{Pd}(\mathrm{II})$. The catalytic behavior of both Merck/Lys-Pd and Merck/Tren-Pd was analyzed in the hydrogenation of 1-octene. The results show that a suitable choice of the complexing function $\mathrm{F}$ of the receptor together with the controlled functionalization of the AC surface is crucial to optimize the efficiency of the catalysts. Moreover, it is also shown the key role of the complexing functions, $\mathrm{F}$, of the Ar-S-F molecules, in the stability of the catalysts, i.e. in 
their reusability. The catalysis results have been compared with these of analogous catalysts based on several solid supports functionalized with $\mathrm{Pd}(\mathrm{II})$.
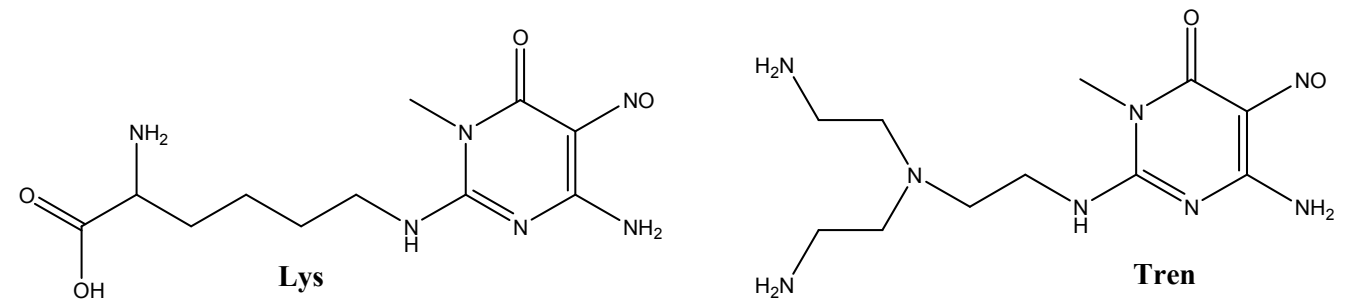

Scheme 2. Molecular structures of the Ar-S-T type molecules used in this work.

\section{Experimental}

\section{Chemicals}

A commercial activated carbon, AC, Merck K24504014 (Merck hereinafter), previously characterized, ${ }^{11,13,14}$ was used as-received. All solvents and other chemicals were of analytical grade and used as received.

The preparation of Lys and Tren compounds was carried out according to a general procedure already reported. ${ }^{42}$ The two compounds were structurally characterized by conventional spectroscopic and analytical techniques. ${ }^{12,15}$

\section{Preparation of the catalysts}

The two catalysts, Merck/Lys-Pd and Merck/Tren-Pd, were prepared according to the two-step procedure of Scheme 1. The first one consisted on the preparation of Merck/Lys and Merck/Tren hybrid materials, which was done following previously described procedures. ${ }^{12,15}$ The amounts of the receptors adsorbed were $0.71 \mathrm{mmol} / \mathrm{g}$, in the case of Lys, and $0.43 \mathrm{mmol} / \mathrm{g}$ in the case of Tren.

In the second step, Merck/Tren-Pd and Merck/Lys-Pd catalysts were prepared by adsorption of $\mathrm{PdCl}_{4}{ }^{2-}$, in water solution, on Merck/Tren and Merck/Lys. The data obtained from these adsorption isotherms at $\mathrm{pH}=4$, enabled us to fit the suitable conditions in order to control the final amounts of Pd(II) on the Merck/Lys-Pd and Merck/Tren-Pd catalysts. 3 grams of Merck/Tren or Merck/Lys were mixed into a $2 \mathrm{~L}$ plastic flask, with $1 \mathrm{~L}$ of a water solution containing $\mathrm{K}_{2} \mathrm{PdCl}_{4}$ and $1 \mathrm{M} \mathrm{KCl}$, so that the molar relationship $\mathrm{K}_{2} \mathrm{PdCl}_{4} / \mathrm{Receptor}=2$ (i.e., $\left[\mathrm{K}_{2} \mathrm{PdCl}_{4}\right]$ was $5 \times 10^{-3} \mathrm{M}$ and $3 \times 10^{-3} \mathrm{M}$ in the case of Merck/Lys and Merck/Tren, respectively). The $\mathrm{pH}$ was set to 4 because it is the optimum value for the $\mathrm{Pd}(\mathrm{II})$ complexation with the free $\mathrm{F}$ functions of the two 
adsorbed receptors (the carboxyl-amine and the tri-amine functions in the case of Lys and Tren, respectively) and also because it guarantees that all the $\mathrm{Pd}(\mathrm{II})$ in solution is as $\mathrm{PdCl}_{4}{ }^{2-}$ anion. ${ }^{43}$ The flasks were shaken into an air-thermostated bath at $298.1 \mathrm{~K}$ up to the equilibrium was reached ( 7 days). Then, the solids were filtered off and washed repeatedly with distilled water. The adsorbed $\mathrm{PdCl}_{4}{ }^{2-}$ was determined by $\mathrm{UV}$ measurements (at $\lambda=471 \mathrm{~nm}$ ) of the initial and equilibrium concentrations of the $\mathrm{PdCl}_{4}{ }^{2-}$ solutions. The obtained values, $0.71 \mathrm{mmol} / \mathrm{g}$ of $\mathrm{PdCl}_{4}{ }^{2-}$ for Merck/Lys and 0.62 $\mathrm{mmol} / \mathrm{g}$ for Merck/Tren, were found to be similar when the adsorbed $\mathrm{PdCl}_{4}{ }^{2-}$ was determined also by ICP-MS analysis (see next paragraph) of the solid samples, namely 0.73 and $0.61 \mathrm{mmol} / \mathrm{g}$.

Unlike Merck-Lys-Pd, which contains Lys (the ligand) and $\mathrm{Pd}(\mathrm{II})$ in equimolar amounts, Merck-Tren-Pd contains molar excess of $\mathrm{Pd}(\mathrm{II})$ in relation to the Tren. With the purpose of getting insight into the possible influence of the excess of metal on the catalytic activity it was also prepared a catalyst based on Tren compound with Tren/ $\mathrm{PdCl}_{4}{ }^{2-}=1 / 1$ molar ratio. This was done as follows: $500 \mathrm{~mL}$ of an aqueous solution $2.2 \cdot 10^{-3} \mathrm{M}$ of $\mathrm{K}_{2} \mathrm{PdCl}_{4}$ at $\mathrm{pH}$, were mixed with $0.500 \mathrm{~g}$ of a previously prepared Merck/Tren material containing $0.20 \mathrm{mmol}$ of Tren per gram, ${ }^{11,44}$ and the suspension was stirred during 7 days. The solid was then separated by filtration, washed repeatedly with distilled water and dried under vacuum. The amount of $\mathrm{Pd}(\mathrm{II})$ retained in this catalyst (which is labelled as Merck/Tren-Pd-1/1), was $0.20 \mathrm{mmol}$ per gram of material.

The elemental analysis $(\mathrm{C}, \mathrm{H}$, and $\mathrm{N}$ ) of the solid samples were obtained by using a Thermo Finnigan, Flash EA 1112 Equipment. The Pd contents of the catalysts were also determined, as follows: c.a. $50 \mathrm{mg}$ of the sample were mixed with $15 \mathrm{~mL}$ of a $\mathrm{H}_{2} \mathrm{SO}_{4} / \mathrm{HNO}_{3}$ mixture $(2 / 1 \mathrm{v} / \mathrm{v})$ and the suspension was then heated under reflux up to total solution of the sample. Then, the solution was slowly evaporated up to dryness and the solid residue was solved in $4 \mathrm{ml}$ of a $\mathrm{HCl} / \mathrm{HNO}_{3}(3 / 1 \mathrm{v} / \mathrm{v})$ solution from which the Pd content was determined by ICP-MS using an AGILENT Mod. Series 7500 equipment.

\section{Nitrogen adsorption isotherms}

The textural characteristics of the parent AC and of the hybrids have been determined by nitrogen adsorption at $77 \mathrm{~K}$ by using ASAP 2020 equipment. The surface areas have 
been obtained by applying the BET equation to the adsorption data and the pore size distributions have been determined by DFT. ${ }^{14,45}$

\section{TEM micrographs}

The morphology of the catalysts has been observed in the TEM images obtained with a JEOl Mod. JEM-2010 equipment of the STI services of the University of Alicante (Spain).

\section{XPS spectra}

The XPS spectra of solid samples were registered with a ESCA5701 instrument (Physical Electronics), by using the Mgka 300W15 kV radiation of the twin anode in the constant analyzer energy mode, with pass energy of 187.85 and $29.35 \mathrm{eV}$ for the survey and high resolution spectra, respectively. The pressure of the analysis chamber was maintained at $10^{-9}$ Torr and the binding energy and the Auger kinetic energy scale were regulated by setting the $\mathrm{C} 1 \mathrm{~s}$ transition at $284.6 \mathrm{eV}$. The accuracy of BE values was $0.2 \mathrm{eV}$. The decovolution of the XPS spectra was done with the Peakfit software. ${ }^{46}$

\section{Catalytic reactions}

The hydrogenation of 1-octene was carried out in a stainless steel $30 \mathrm{~mL}$ Parr reactor, using c.a. $20 \mathrm{mg}$ of the hybrid catalyst, $5 \mathrm{mmol}$ of the substrate and $15 \mathrm{~mL}$ of methanol as solvent. Two series of experiments were carried out using the Merck/Lys-Pd and Merck/Tren-Pd catalysts: in the first one, the temperature, the hydrogen pressure and the substrate to catalyst molar ratio were $323.1 \mathrm{~K}, 15$ bar and 360:1, respectively. In the second, these parameters were set to $303.1 \mathrm{~K}, 1.5$ bar and 360:1. Moreover, an additional catalytic essay was performed at 303.1 K, 1.5 bar and 1300:1 molar ratio, using the catalyst Merck/Tren-Pd-1/1.

The analysis of the reaction products was performed at the end of each experiment using a 7820A Agilent GC System chromatograph, with an Agilent 190915-433 column, 30 m x $250 \mu \mathrm{m}$ x $25 \mu \mathrm{m}$ and a FID detector.

To study the potential reutilization of the Merck/Lys-Pd and Merck/Tren-Pd catalysts, these catalysts were filtered in air after each reaction run, thoroughly washed with methanol, and then used in a new catalytic test under the same conditions. 


\section{Results and discussion}

\section{Characterization of Merck/Tren and Merck/Lys}

The analytical data and the XPS spectra of Merck/Tren and Merck/Lys (used to subsequently obtain Merck/Tren-Pd and Merck/Lys-Pd catalysts) have been already reported. ${ }^{12,14,15,17}$

The adsorption-desorption isotherms of $\mathrm{N}_{2}$ on both hybrid materials together with these of Merck are shown in Figure 1. The pore size distributions obtained from the isotherms are collected in Figure 2. The isotherms are of Type IV according to the IUPAC classification and they show hysteresis loops which suggest the existence of mesopores. According to what it is seen in figure 1, the BET surface area decreases from $854 \mathrm{~m}^{2} / \mathrm{g}$ (of Merck) to $474 \mathrm{~m}^{2} / \mathrm{g}$ of Merck/Lys $\left(0.71 \mathrm{mmol} / \mathrm{g}\right.$ ) and to $495 \mathrm{~m}^{2} / \mathrm{g}$ of Merck/Tren $(0.43 \mathrm{mmol} / \mathrm{g})$. Figure 2 shows that these decreases are mainly due to drop of the volume of small micro-pores in particular those of size smaller than c.a. $3 \mathrm{~nm}$. This probably means that the adsorption of Lys and Tren is blocking the entrances of such micro-pores.
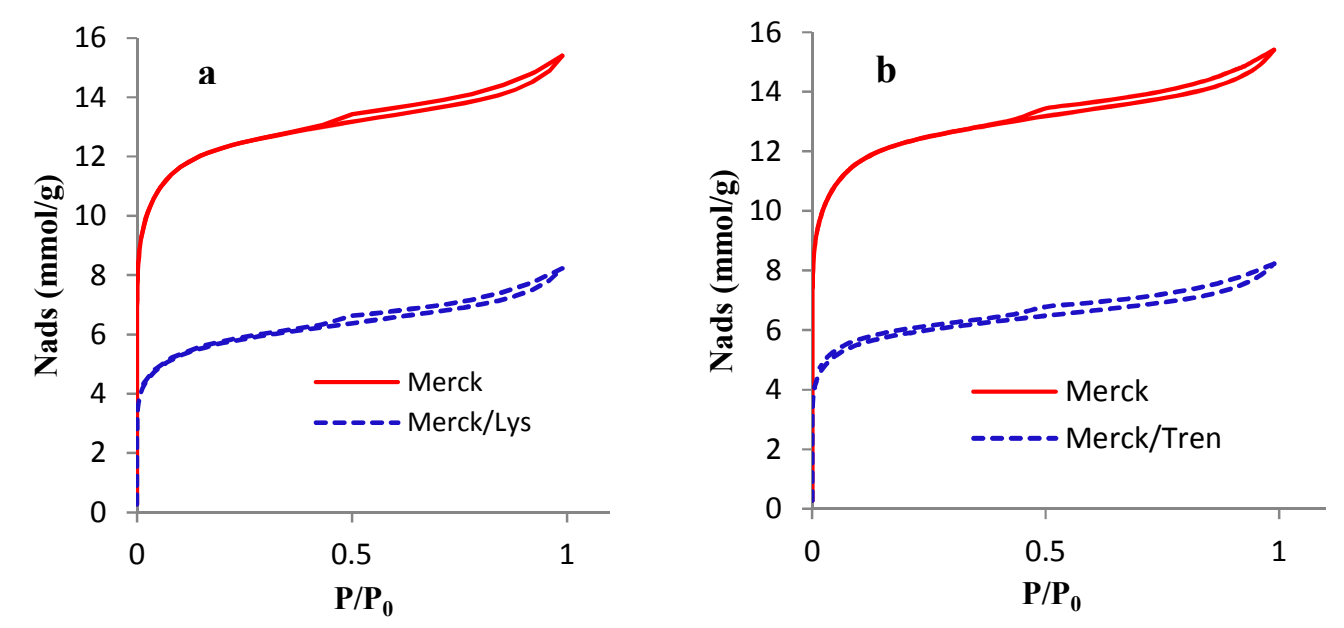

Figure 1. Nitrogen adsorption-desorption isotherms on: a) Merck and Merck/Lys hybrid; b) Merck and Merck/Tren hybrid. 

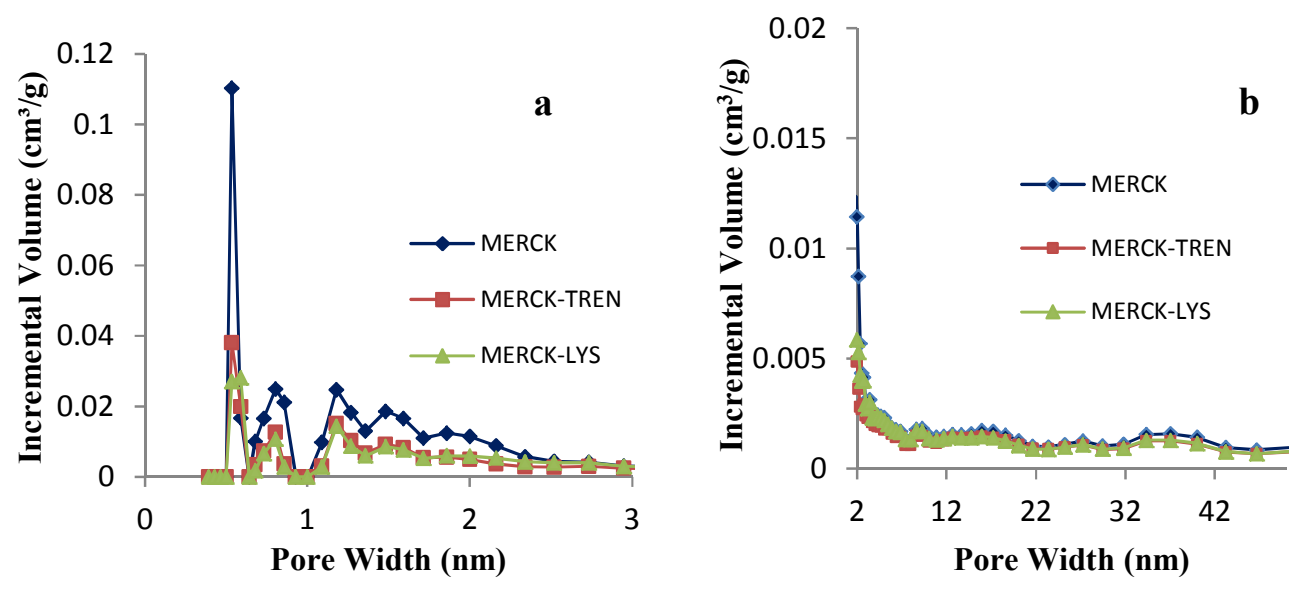

Figure 2. Pore volume distributions of Merck, Merck/Tren, and Merck/Lys , a) micropores range, b) meso-pores range.

The comparison of the proton isotherms of Merck ${ }^{11}$ with these of Merck/Tren ${ }^{47}$ and Merck/Lys (Figure 3) suggests that the acid-base properties of the function $F$ of Tren and Lys, have been efficiently transferred to the hybrids. Thus, the acid-base profile of Merck/Tren surface is in agreement with the existence of small amounts of carboxyl (pKa of c.a. 3) and phenol plus lactone groups (pKa c.a. 10) of the AC Merck, but also with the presence of protonated amino groups of the $\mathrm{F}$ function (triamine) of Tren at $\mathrm{pH}$ values between 7.8 to $11.4{ }^{47}$ The Merck/Lys surface only exhibits the carboxyl, lactone and phenol groups of the $\mathrm{AC}$, as the zwitterionic carboxyl-ammonium function $\mathrm{F}$ of this receptor lacks of acid-base properties in the 2.5-9.0 $\mathrm{pH}$ range which causes that the profiles of Merck/Lys and Merck are very similar. The positive surface charge of Merck/Lys and Merck in the 2.5-9.0 $\mathrm{pH}$ range is assigned to the protonation of the arene centers at the surface of both materials. Thus the smaller value of such charge of Merck/Lys than that of Merck is due to the partial blocking of such centers by the pyrimidine plane of the adsorbed Lys molecules. Therefore, these results suggest that the $\mathrm{F}$ functions of the adsorbed Tren and Lys keep free and maintain their complexing abilities to $\operatorname{Pd}(\mathrm{II}){ }^{13,17,48}$

It is worth mentioning the lack of protonation of the $\mathrm{C}(5)-\mathrm{NO}$ groups of both adsorbed receptors in the hybrid materials. The attachment of the proton to this group in the free receptor is coplanar with the pyrimidine plane, ${ }^{49}$ in the c.a. $1.0-2.5 \mathrm{pH}$ range. ${ }^{11,15}$ This 
means that this protonation is hindered on the adsorbed receptor due to the $\pi-\pi$ interaction of the pyrimidine plane with the arene centers.

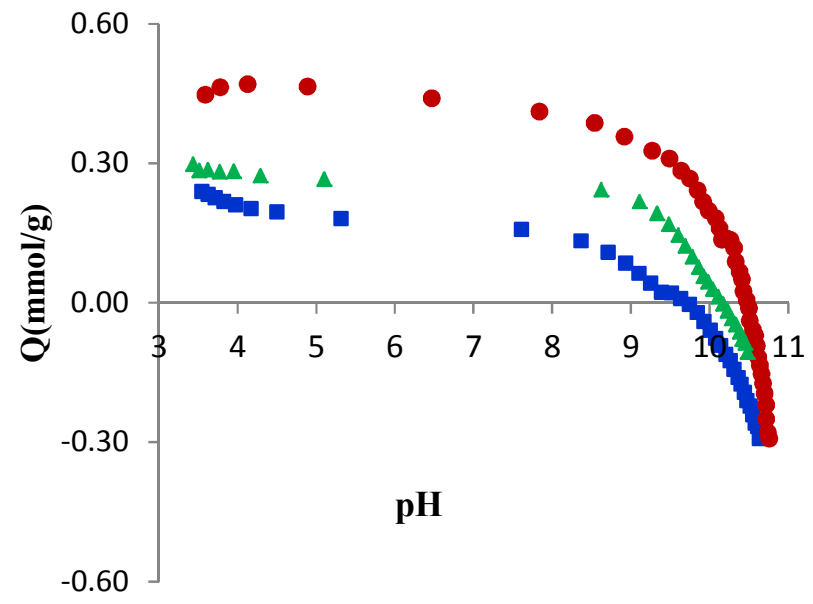

Figure 3. Plots of the surface change density (Q) vs pH for Merck ( $\boldsymbol{\Delta})$, Merck/Tren $(\bullet)$, and Merck/Lys ( $\mathbf{\square})$.

\section{Characterization of the catalysts}

As already commented the two catalysts, Merck/Lys-Pd and Merck/Tren-Pd, were prepared by adsorption of $\mathrm{PdCl}_{4}{ }^{2-}$ on Merck/Lys and Merck/Tren hybrid materials (see experimental section). Their chemical compositions are summarized in Table 1 together with this of the AC Merck. The nitrogen and Pd contents are in agreement with the amounts of the adsorbed receptors and the adsorbed $\mathrm{PdCl}_{4}{ }^{2-}$ respectively (see Experimental Section).

Table 1. Analytical composition (\% by weight) of Merck and of the catalysts.

\begin{tabular}{cccccc}
\hline Material & $\mathbf{C}(\%)$ & $\mathbf{H}(\%)$ & $\mathbf{N}(\%)$ & $\mathbf{O ~ ( \% )})^{\mathbf{a}}$ & Pd (\%) $^{\mathbf{b}}$ \\
\hline Merck & 94.70 & 0.30 & 0.75 & 4.25 & - \\
Merck/Lys-Pd & 76.00 & 1.50 & 5.72 & 9.22 & 7.70 \\
Merck/Tren-Pd & 80.00 & 1.25 & 4.81 & 7.36 & 6.63 \\
\hline
\end{tabular}

${ }^{\mathrm{a}}$ Obtained as residuals. ${ }^{\mathrm{b}}$ Obtained by ICP-MS. 
The N1s signals of the XPS spectra of Merck/Lys-Pd and Merck/Tren-Pd are assigned to the nitrogen atoms of the receptor molecules, Lys and Tren, as this component is absent in the spectrum of Merck. ${ }^{12,15}$ These N1s signals (see Figure 4) consists of three components which have very similar energy values to these in the corresponding precursors Merck/Lys and Merck/Tren. ${ }^{12,15}$ The one at $398.7 \mathrm{eV}$, for Merck/Lys-Pd, and at 399.4, for Merck/Tren-Pd, is assigned to aliphatic nitrogen. The component at 400.0 $\mathrm{eV}$ in both cases is assigned to $\mathrm{N}(1)+\mathrm{C}(5) \mathrm{NO}$ groups and the one $401.0 \mathrm{eV}$ in both cases to $\mathrm{C}(2) \mathrm{NH}+\mathrm{N}(3)+\mathrm{C}(4) \mathrm{NH}_{2}$. These data suggest that the nature of Merck/receptor hybrid materials remains unaffected after the adsorption of $\mathrm{Pd}(\mathrm{II})$. The $\operatorname{Pd}_{3 \mathrm{~d} / 2}$ and $\operatorname{Pd}_{3 \mathrm{~d}}$ 5/2 signals of both catalysts, at $343.0 \mathrm{e} . \mathrm{V}$. and $337.5 \mathrm{eV}$, are characteristics of adsorbed $\mathrm{Pd}(\mathrm{II})$, which discards any metal reduction. Moreover, the $\mathrm{Pd} / \mathrm{Cl}$ molar ratio obtained from the $\mathrm{Pd}$ and $\mathrm{Cl}$ signals of the XPS spectra are very close to $1 / 2$ for Merck/Lys-Pd and to $1 / 3$ for Merck/Tren-Pd, respectively.
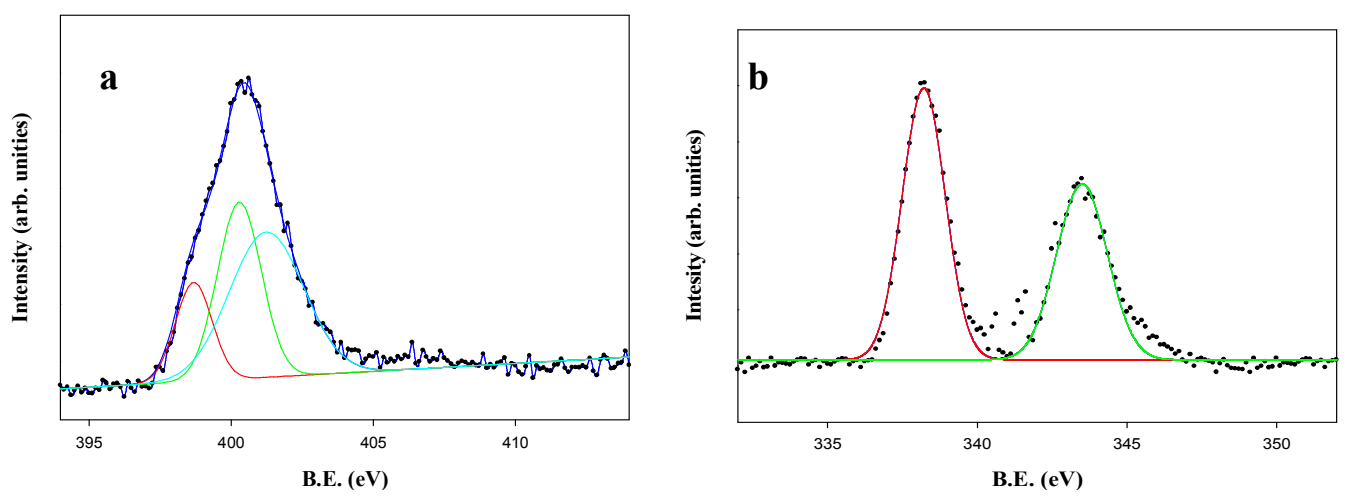

Figure 4. XPS spectra of: a) $\mathrm{N}_{1 \mathrm{~s}}$ region of Merck/Lys-Pd catalyst. b) $\mathrm{Pd}_{3 \mathrm{~d}} 5 / 2$ and $\mathrm{Pd}_{3 \mathrm{~d}} 3 / 2$ regions of Merck/Tren-Pd catalyst.

These data point out that $\mathrm{Pd}(\mathrm{II})$ in Merck/Lys-Pd is forming the bidentate complex $\left[\mathrm{Pd}\left(\mathrm{COO}--\mathrm{CHR}_{-} \mathrm{NH}_{2}\right) \mathrm{Cl}_{2}\right]$ with Lys, and in Merck/Tren-Pd the tridentate $\left[\mathrm{Pd}\left(\mathrm{NH}_{2}-\right.\right.$ $\left.\left.\left(\mathrm{CH}_{2}\right)_{2}-\mathrm{NHR}-\left(\mathrm{CH}_{2}\right)_{2}-\mathrm{NH}_{2}\right) \mathrm{Cl}\right]$ with Tren. Moreover, this statement is also supported by the higher binding ability to $\mathrm{Pd}(\mathrm{II})$ of the triamine function of Tren (see Supplementary Information) in relation to that of the COO--CHR- $-\mathrm{NH}_{2}$ function of Lys. ${ }^{50,51}$ Therefore, other possible competitive adsorption sites (the arene centers, $\mathrm{C} \pi{ }^{47,52}$ and the oxygen functions of the AC) can be discarded. As commented in the Experimental 
Section, in the case of Merck/Tren-Pd the amount of $\mathrm{PdCl}_{4}{ }^{2-}$ exceeds this of Tren. Therefore, it is expected the amount in excess is adsorbed by $\pi-\pi$ interactions of this planar anion with planar arene centers. ${ }^{53}$

The effect of the adsorption of $\mathrm{Pd}(\mathrm{II})$ on the surface area of the catalyst is negligible (495 and $490 \mathrm{~m}^{2} \mathrm{~g}^{-1}$ for Merck/Lys and Merck/Lys-Pd, respectively). This is due to the whole $\mathrm{Pd}(\mathrm{II})(0.71 \mathrm{mmol} / \mathrm{g})$ is adsorbed vía complexation with the $\mathrm{COO}--\mathrm{CHR}-\mathrm{NH}_{2}$ function of Merck/Lys $(0.71 \mathrm{mmol} / \mathrm{g})$. Nevertheless, in the case of Merck/Tren-Pd there is a decrease of the surface area $\left(405 \mathrm{~m}^{2} \mathrm{~g}^{-1}\right)$ with respect to the Merck/Tren hybrid (475 $\left.\mathrm{m}^{2} \mathrm{~g}^{-1}\right)$ (see Figure $1 \mathrm{~b}$ ). This is due to the amount of $\mathrm{Pd}(\mathrm{II})$ adsorbed $\left(0.62 \mathrm{mmol} \mathrm{g}^{-1}\right)$ is higher than the receptor Tren $\left(0.43 \mathrm{mmol} \mathrm{g}^{-1}\right)$. As already commented, it is expected that the $\mathrm{PdCl}_{4}{ }^{2-}$ in excess $(0.19 \mathrm{mmol})$ is adsorbed via $\mathrm{C} \pi-\mathrm{d} \pi$ (plane to plane) interactions with the graphitic surface, ${ }^{53}$ which is probably the reason of the decrease of the BET surface area.

\section{Catalytic Hydrogenation of 1-octene with $\mathrm{H}_{2}$}

The catalytic activity of Merck/Lys-Pd and Merck/Tren-Pd hybrids in the $\mathrm{H}_{2}$ hydrogenation of 1-octene in methanol was studied at $323.1 \mathrm{~K}$ and $\mathrm{P}_{\mathrm{H} 2}=15$ bar. The reaction was carried out keeping the molar relationship 1 -octene/Pd(II) $=360$ in both cases. The two catalysts have shown high activity, being n-octane the only product at the end of the reaction.

Figure 5, shows the conversion v.s. time plots for both catalysts. It is seen that $100 \%$ of conversion to n-octane is reached after 2 hours in the case of Merck/Lys-Pd and after 2.5 hours in the Merck/Tren-Pd. This figure also shows that 2-octene is formed as well (in maximum amounts of c.a. 20\%) in the course of the reactions, although it becomes completely hydrogenated, in both cases, after the total consumption of 1-octene. Thus, the only final product of the reaction is n-octane. The TOF values (mmol 1octene/mmol Pd(II) transformed by second) were $0.052 \mathrm{~s}^{-1}$ and $0.036 \mathrm{~s}^{-1}$ for Merck/Lys$\mathrm{Pd}$ and Merck/Tren-Pd, respectively. Having in mind that the catalytic active species $\mathrm{PdCl}_{4}{ }^{2-}$ with TOF $=0.013 \mathrm{~s}^{-1}$ is present in Merck/Tren-Pd surface (see below), a derived TOF value of $0.023 \mathrm{~s}^{-1}$ accounts for the real catalytic activity of Tren-Pd anchored complex. These values are significantly larger than those reported for similar reactions catalyzed by $\operatorname{Pd}(\mathrm{II})$-amino complexes supported on both resins and activated carbons. ${ }^{38,54}$ This improvement is probably due to the homogeneous dispersion of the 
catalytic centers in these catalysts provides an easy accessibility of the substrates to them.
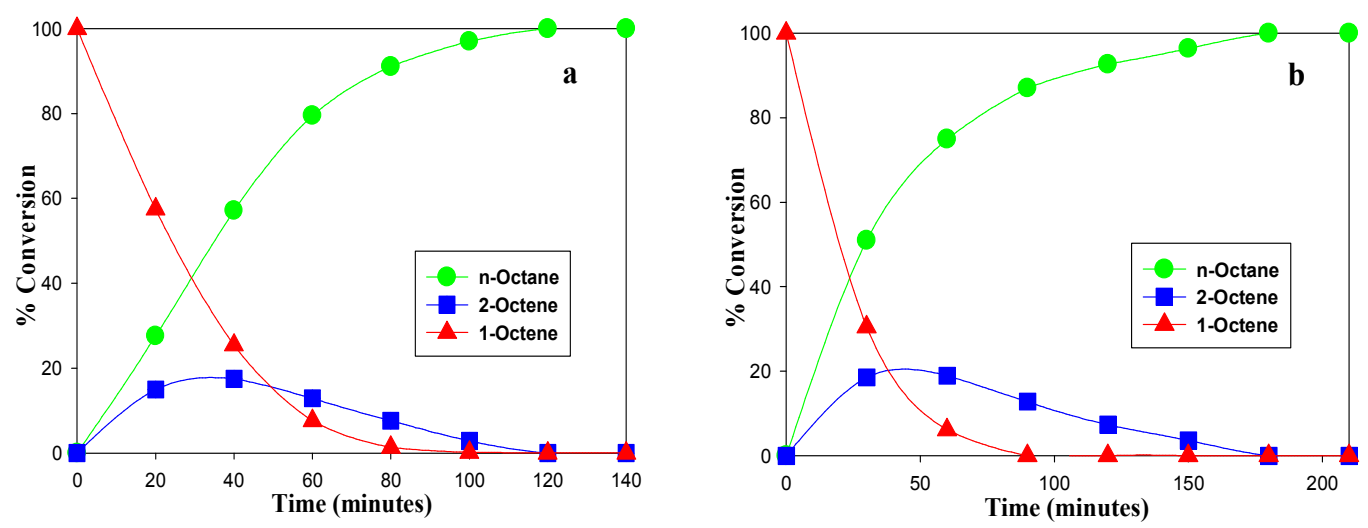

Figure 5. Conversion v.s. time plots for the hydrogenation of 1 -octene at $\mathrm{p}=15$ bar and $\mathrm{T}=323.1 \mathrm{~K}$ using as catalyst: a) Merck/Lys-Pd and b) Merck/Tren-Pd.

The hydrogenation of 1-octene in the same experimental conditions, i.e. in methanol, at $\mathrm{P}_{\mathrm{H} 2}=15$ bar and $\mathrm{T}=323.1 \mathrm{~K}$ has also been studied: i) without any catalyst, ii) with AC Merck, iii) with Merck/Lys and iv) with Merck/Tren. The reaction required very high reaction times in the four cases (c.a. 14 hours), and the yields were significantly smaller (40.9\% in the first case and c.a. $20 \%$ when Merck, Merck/Tren or Merck/Lys were used as catalysts). In addition Merck-[ $\left.\mathrm{PdCl}_{4}\right]$ was also used as catalyst. The reaction time in this case was 2,5 hours and c.a. $100 \%$ conversion of 1-octene was obtained, although the selectivity ( $48 \%$ of octane formed) was very poor. Similar trials with LysPd and Tren-Pd as catalysts could not be carried out because none of them can be isolated. Thus, the high selectivity (100\% conversion to octane) and the short reaction times needed with Merck/Tren-Pd and Merck/Lys-Pd is ascribed to the chemical nature of the Pd(II)-complexes is kept in the catalysts and to the easy accessibility to the active sites. The larger conversion time required with Merck/Tren-Pd catalyst ( 2.5 hours) than with Merck/Lys-Pd (2.0 hours) is probably related to both the presence in the former of $\mathrm{PdCl}_{4}{ }^{2-}$ which is less active (see above) and to the less amount of Tren-Pd (0.43 $\mathrm{mmol} / \mathrm{g})$ active centres in the former than Lys-Pd $(0.71 \mathrm{mmol} / \mathrm{g})$ in the second.

The isomerization of 1-octene to 2-octene in the hydrogenation catalyzed by $\mathrm{Pd}(\mathrm{II})$ complexes takes place by the formation of an intermediate which consists of 1-octene and $\mathrm{H}_{2}$ coordinated to $\mathrm{Pd}(\mathrm{II})$. This intermediate favors the migration of the $\pi$ electron 
pair of the $\mathrm{C}(1)=\mathrm{C}(2)$ double bond through the $\mathrm{Pd}(\mathrm{II})$ centres, forming the 2-octene isomer. ${ }^{55-57}$ Thus, the formation of 2-octene in the course of the reaction supports that the Pd(II) complexes anchored on the Merck surface are the active sites. Besides, the coordination of the substrates to $\mathrm{Pd}(\mathrm{II})$ centers causes also that almost the whole $\mathrm{Pd}(\mathrm{II})$ is reduced to $\operatorname{Pd}(0)$ during the reaction (see below) ${ }^{58}$ In fact, any $\operatorname{Pd}(\mathrm{II})$ reduction was observed when the catalysts suspended in $\mathrm{MeOH}$ were treated in absence of 1-octene (which rules out the formation of the above intermediate species), with a $\mathrm{H}_{2}$ flow at 15 bar pressure and $\mathrm{T}=323.1 \mathrm{~K}$.

Figures 6 and 7 show the $\operatorname{Pd}_{3 \mathrm{~d} 5 / 2}$ and $\mathrm{Pd}_{3 \mathrm{~d}}$ /2 signals of the XPS spectra and TEM images of both catalysts before and after been used in the reaction. It is seen (Figure 6) that the reduction of $\operatorname{Pd}(\mathrm{II})$ to $\operatorname{Pd}(0)$ is practically complete which results in the formation of $\operatorname{Pd}(0)$ nanoparticles on the surface of the catalysts (Figure 7$)$. The particle size distributions obtained from the analysis of TEM images are collected in Figure 8. Although some sintering is seen, most of them (85\% in the case of Merck/Tren-Pd and c.a. $75 \%$ in Merck/Tren-Lys) have sizes smaller than $12 \mathrm{~nm}$ (Figure 8). It is worth mentioning that these particle sizes are smaller than other obtained in $\operatorname{Pd}(0) / A C$ hybrid materials in which the AC was not specifically functionalized. ${ }^{59}$ The fact that we have obtained smaller particles sizes can be ascribed to the reduction of Pd(II) of Merck/Lys$\mathrm{Pd}$ and Merck/Tren-Pd catalysts to $\mathrm{Pd}(0)$ is controlled by the complexation of $\mathrm{Pd}(\mathrm{II})$ by the receptors. ${ }^{60}$
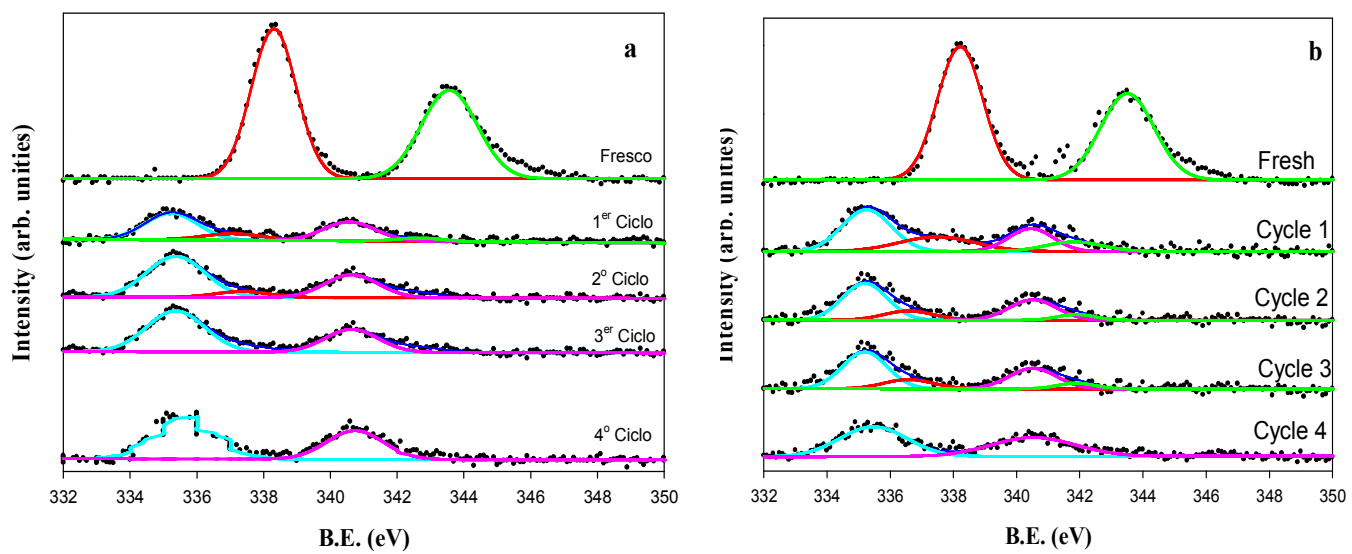

Figure 6. $\operatorname{Pd}_{3 \mathrm{~d} 5 / 2}$ and $\mathrm{Pd}_{3 \mathrm{~d} 3 / 2}$ signals of the XPS spectra of both catalysts before and after several reaction cycles at $323.1 \mathrm{~K}$ and $\mathrm{p}_{\mathrm{H} 2}=15$ bar: a) Merck/Lys-Pd catalyst; b) Merck/Tren-Pd catalyst. 

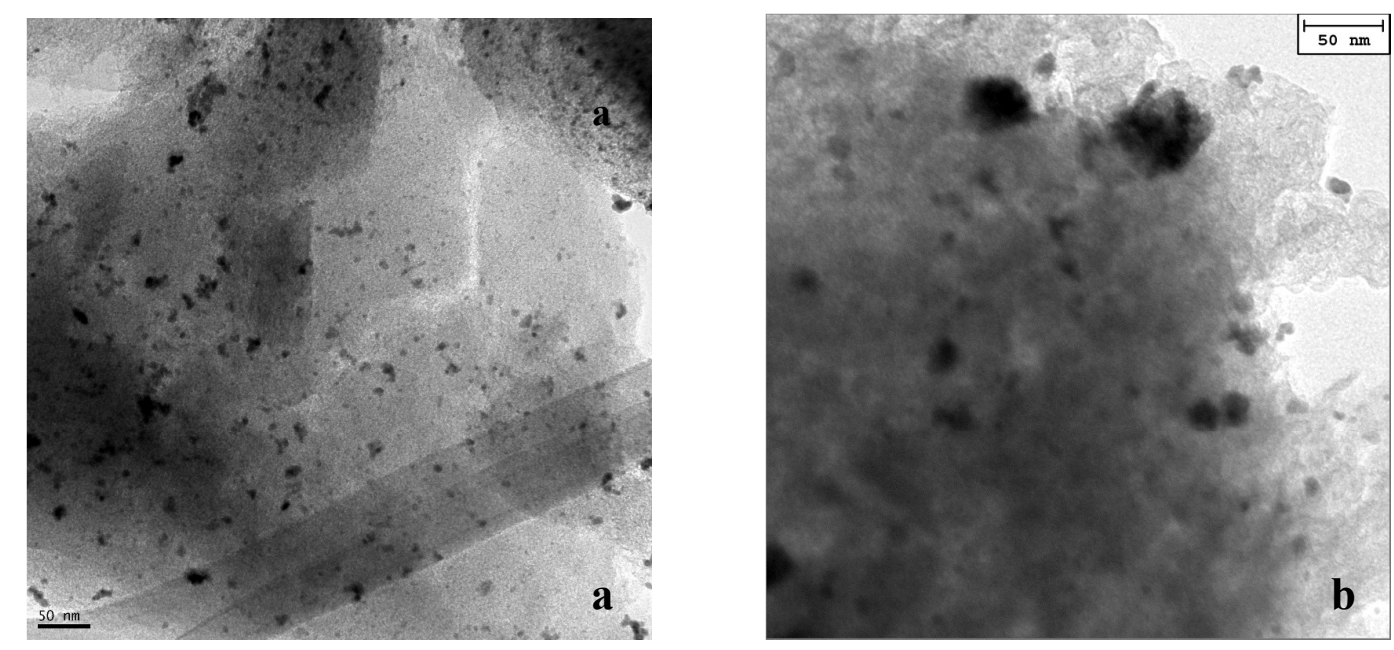

Figure 7. TEM images of the catalysts after the first reaction cycle performed at $323.1 \mathrm{~K}$ and $\mathrm{p}_{\mathrm{H} 2}=15$ bar: a) Merck/Lys-Pd catalyst; b) Merck/Tren-Pd catalyst.

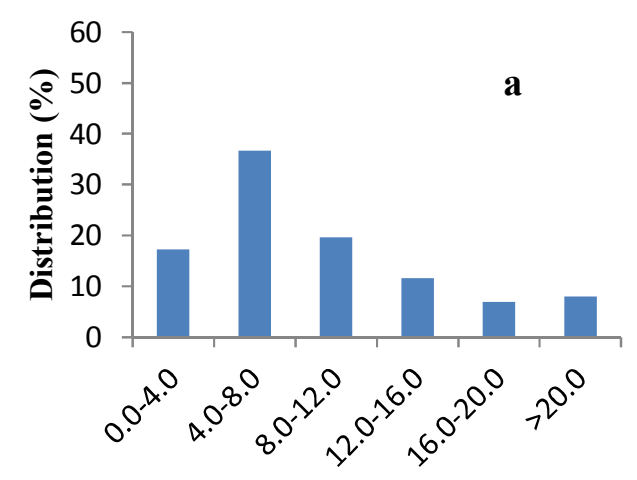

Size (nm)

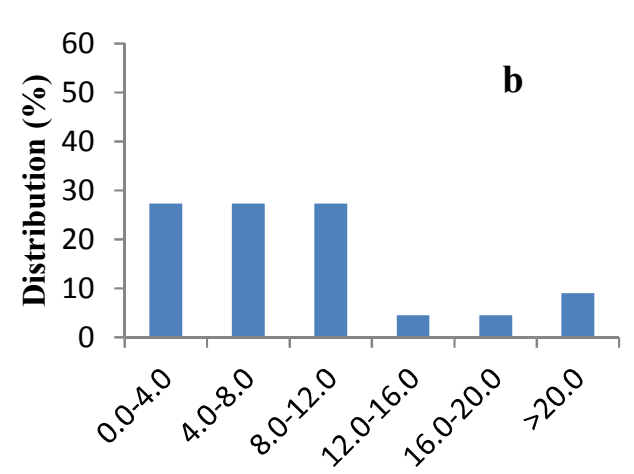

Size (nm)

Figure 8. Particle size distribution of the $\operatorname{Pd}(0)$ nanoparticles on the catalyst after the first reaction cycle performed at $323.1 \mathrm{~K}$ and $\mathrm{p}_{\mathrm{H} 2}=15$ bar: a) Merck/Lys-Pd catalyst; $b$ ) Merck/Tren-Pd catalyst.

\section{Stability of the catalysts}

The chemical compositions of the catalysts before and after being used in four reaction cycles are collected in Table 2. This table also contains the values of the factor $\mathrm{R}$ whose meaning is addressed later. The values in Table 2 indicate some leaching of the starting material after the first reaction cycle as it is suggested by the $\mathrm{N}$ and Pd losses. 
Nevertheless, after the first cycle the elemental composition of the catalyst keeps constant. The nature of the removed material during the first reaction cycle was determined by mass spectra analysis of the reaction mixtures which revealed the presence of $\mathrm{NH}_{2}-\mathrm{S}-\mathrm{F}$ residues. Besides, the UV spectra of the reaction mixtures did not show any of the characteristic bands of the pyrimidine residue of the receptors. ${ }^{12,61}$ This suggests that the nitrogen and $\mathrm{Pd}$ losses are probably due to the solvolytic process: $\mathrm{MeOH}+\mathrm{C}(2)_{\mathrm{Ar}}-(\mathrm{NH})-\mathrm{S}-\mathrm{F} \rightarrow \mathrm{C}(2)_{\mathrm{Ar}} \mathrm{OMe}+\mathrm{NH}_{2}-\mathrm{S}-\mathrm{F}$. This process affects the $\mathrm{C}(2)$ position of the pyrimidine residue of the anchored receptors (see Scheme 2), although such pyrimidine residue remains anchored to the CA surface. Similar partial solvolytic process has been reported for this class of receptors in water. ${ }^{62}$

Moreover, previous studies have shown that the partial solvolysis only affects to those molecules that are subjected to severe stereochemical constraints affecting their -NH-S$\mathrm{F}$ residues. It has also been shown that this is more probable in those molecules which are adsorbed into the narrowest pores. ${ }^{14}$

Table 2. Chemical composition of the catalysts before and after being used $(\mathrm{P}=15$ bar; $\mathrm{T}=323.1 \mathrm{~K})$.

\begin{tabular}{cccccccc}
\hline Catalyst & $\begin{array}{c}\text { Reaction } \\
\text { Cycle }\end{array}$ & $\mathbf{C}(\%)$ & $\mathbf{H}(\%)$ & $\mathbf{N}(\%)$ & $\mathbf{O}(\%)^{\mathbf{a}}$ & $\left.\mathbf{P d}^{(\%)}\right)^{\mathbf{b}}$ & R Factor* $^{*}$ \\
& Fresh & 76.00 & 1.50 & 5.72 & 9.22 & 7.70 & 46.9 \\
Merck/Lys-Pd & 1 & 82.05 & 1.25 & 3.79 & 8.46 & 5.51 & 20.7 \\
& 2 & 81.97 & 1.60 & 3.43 & 7.14 & 4.53 & 18.4 \\
& 3 & 82.25 & 1.45 & 3.50 & 7.47 & 5.32 & 17.8 \\
\hline & 4 & 82.50 & 1.30 & 3.66 & 6.44 & 6.09 & 9.9 \\
\hline Merck/Tren-Pd & 1 & 83.57 & 1.76 & 3.38 & 7.42 & 3.87 & 21.5 \\
& 2 & 83.49 & 1.66 & 2.88 & 7.44 & 4.40 & 19.1 \\
& 3 & 84.01 & 2.00 & 2.80 & 7.46 & 3.72 & 20.5 \\
& 4 & 85.00 & 1.60 & 2.75 & 7.29 & 3.35 & 21.4 \\
\hline
\end{tabular}

${ }^{\mathrm{a}}$ Obtained as residual; ${ }^{\mathrm{b}}$ Obtained by ICP-MS; *See text. 
The above solvolytic process affects the two catalysts in similar extension, i.e. to c.a. $31 \%$ of the receptor molecules in the case of Merck/Tren-Pd and to $35 \%$ in Merck/Lys-Pd. The Pd loss is similar (c.a. $31 \% \mathrm{mmol}$ ) to the amount of $\mathrm{NH}_{2} \mathrm{~S}-\mathrm{F}-\mathrm{Pd}$ evolved due to the solvolysis in the case of the latter. Nevertheless, in the case of Merck/Tren-Pd, the Pd loss (c.a. 50\%) largely exceeds the lixiviated $\mathrm{NH}_{2}-\mathrm{S}-\mathrm{F}-\mathrm{Pd}$. This is probably related to this catalyst contains both $\mathrm{Pd}(\mathrm{II})$ complexed with the triamine function of Tren and adsorbed $\mathrm{PdCl}_{4}{ }^{2-}$. Thus, the difference is probably due to the desorption of most of the adsorbed $\mathrm{PdCl}_{4}{ }^{2-}$.

Thus, the above data points out that both catalysts underwent some leaching derived from the solvolysis of the $\mathrm{NH}_{2}-\mathrm{S}-\mathrm{F}-\mathrm{Pd}$ residue (in the case of Merck/Lys/Pd) and from the solvolysis of the $\mathrm{NH}_{2}-\mathrm{S}-\mathrm{F}-\mathrm{Pd}$ plus the desorption of $\left[\mathrm{PdCl}_{4}\right]^{2-}$ in the case of Merck/Tren/Pd.

After the first reaction cycle, the catalysts were used in three additional cycles under the same reaction conditions. The data of catalytic activity are shown in Table 3 and those of chemical composition in Table 2. Unlike to the first reaction cycle, the analytical values of Table 2 suggest that no leaching occurs during the 2-4 reaction cycles.

Table 3. Data of the catalytic activity of Merck/Lys-Pd and Merck/Tren-Pd ( $\mathrm{P}=15$ bar; $\mathrm{T}=323.1 \mathrm{~K})$.

\begin{tabular}{|c|c|c|c|c|c|c|}
\hline Catalyst & Cycle & $\begin{array}{l}\text { Time } \\
\text { (min) }\end{array}$ & $\begin{array}{c}\text { Total } \\
\text { Conversion } \\
(\%)\end{array}$ & $\begin{array}{c}\text { Conv. } \\
\text { octane } \\
(\%)\end{array}$ & $\begin{array}{c}\text { Conv. 2- } \\
\text { octene } \\
(\%)\end{array}$ & TOF $\left(s^{-1}\right)$ \\
\hline \multirow{4}{*}{ Merck/Lys-Pd } & 1 & 120 & 100 & 100 & - & 0.052 \\
\hline & 2 & 120 & 94.84 & 88.56 & 6.27 & 0.046 \\
\hline & 3 & 120 & 84.66 & 75.93 & 8.73 & 0.040 \\
\hline & 4 & 120 & 78.79 & 70.08 & 8.72 & 0.037 \\
\hline \multirow{4}{*}{ Merck/Tren-Pd } & 1 & 180 & 100 & 100 & - & 0.036 \\
\hline & 2 & 150 & 100 & 100 & - & 0.044 \\
\hline & 3 & 150 & 100 & 100 & - & 0.044 \\
\hline & 4 & 180 & 100 & 100 & - & 0.036 \\
\hline
\end{tabular}


Nevertheless, constant deactivation is shown by the decrease of activity from the first cycle (100\% conversion to n-octane) to the fourth (c.a. $79 \%$ conversion) in the case of Merck/Lys-Pd catalyst. Moreover some amount of 1-octene (c.a. $6 \%$ and $9 \%$ ) is transformed into 2-octene in the three last cycles. In addition, the TOF values steadily decrease from $0.052 \mathrm{~s}^{-1}$ to 0.037 . The XPS spectra (Figure 2) and the TEM micrographs of the catalysts after being used in each reaction cycle support that the $\mathrm{Pd}$ is present as $\operatorname{Pd}(0)$ nanoparticles on the AC surface. These facts lean us to think that the loss of catalytic activity of Merk/Lys-Pd could be due to changes in the $\operatorname{Pd}(0)$ particle size. These changes can be easily assessed from the analysis of the $\mathrm{R}$ parameter $(\mathrm{R}=$ $(\mathrm{Pd} / \mathrm{C})_{\mathrm{XPS}} /(\mathrm{Pd} / \mathrm{C})_{\mathrm{EA}}$, being $(\mathrm{Pd} / \mathrm{C})_{\mathrm{XPS}}$ obtained from the intensities of $\mathrm{Pd}$ and $\mathrm{C}$ components of the XPS spectra and $(\mathrm{Pd} / \mathrm{C})_{\mathrm{EA}}$ from the analytical data). ${ }^{63}$ As the chemical composition (i.e. the $\mathrm{Pd}$ and $\mathrm{C}$ contents) of the catalysts doesn't vary significantly after the first reaction cycle, the $\mathrm{R}$ parameter has to remain constant during the three last reaction cycles should any sintering of $\operatorname{Pd}(0)$ nanoparticles occurs. The values in table 2 show that $\mathrm{R}$ decreases from 46.9, of the fresh Merck/Lys-Pd catalyst to 20.7, after the first reaction cycle which is consistent with the lixiviation of $\mathrm{Pd}$ and the reduction of the remaining $\operatorname{Pd}(\mathrm{II})$ to $\operatorname{Pd}(0)$ (see above). Nevertheless, the steady decrease of $\mathrm{R}$ from 20.7 , to 9.9 from the second to the fourth cycle, due to the decrease in the intensity of the $\operatorname{Pd}_{\mathrm{XPS}}$ signal, clearly suggests the sintering of the $\operatorname{Pd}(0)$ particle when the catalyst is reused.

The sintering of the $\operatorname{Pd}(0)$ particles formed after the first reaction cycle was assessed by measuring the mean particle sizes in TEM images of Merck/Lys-Pd catalyst after the first and fourth cycles. The values change from $7.3 \mathrm{~nm}$ to $13.3 \mathrm{~nm}$, which clearly agrees with the conclusions obtained from the above analysis of the $\mathrm{R}$ values.

The data in Table 3 also show that Merck/Tren-Pd keeps its efficiency when it is reused (100\% conversion to n-octane and constant TOF values) in three additional cycles. Moreover, this catalyst does not undergo significant changes in the chemical composition which suggests that no further solvolysis of the S-F residue or Pd loss occurs under reusing. Nevertheless, unlike Merck/Lys-Pd, the value of $\mathrm{R}$ for Merck/Tren-Pd decreases from 52.7 to 21.5 in the first reaction cycle (due to lixiviation of Pd) but it remains constant after three additional ones, pointing out insignificant aggregation of the $\operatorname{Pd}(0)$ nanoparticles. We could not carried out in this case the assessment of no aggregation of the $\operatorname{Pd}(0)$ nano-particles after reusing the catalyst due to the number of particles to be analysed was very low. These results show that the 
structural stability of the catalysts obtained after the first reaction cycle is crucial for preserving their catalytic activities. Thus, the higher stability of Merck/Tren-Pd (i.e., higher catalytic efficiency) has to be related with the binding ability of the triamine function of Tren to $\operatorname{Pd}(0)$ nanoparticles is higher than this of the COO-- $\mathrm{CHR}-\mathrm{NH}_{2}$ function of Lys in Merck/Lys-Pd. ${ }^{50,51}$

\section{Influence of temperature and pressure on the stability of Merck/Lys-Pd and Merck/Tren-Pd catalysts}

The reaction was carried out at $\mathrm{T}=303.1 \mathrm{~K}$ and $\mathrm{P}=1.5$ bar to study the influence of the pressure and the temperature on the catalytic behavior of Merck/Lys-Pd and Merck/Tren-Pd. The reactivity data of four reaction cycles are summarized in Table 4. When Merck/Lys-Pd is used, the total conversion of 1-octene was obtained in the four reaction cycles with little amounts of 2-octene (between $0.0 \%$ to $4.6 \%$ ) as reaction byproduct. These results clearly improve those obtained when the reaction was carried out at $\mathrm{T}=323.1 \mathrm{~K}$ and $\mathrm{P}=15$ bar (Table 3 ). Nevertheless, these milder reaction conditions require a much larger reaction time: $240 \mathrm{~min}$, i.e. almost twice that needed in the previous conditions. Moreover, the TOF values, $0.026 \mathrm{~s}^{-1}$ for the four reaction cycles, are almost half of these previously obtained.

The composition and the XPS spectra of the fresh and reused catalysts are collected in Table 5 and Figure 9, respectively. The data of Merck/Lys-Pd in Table 5 shows that the nitrogen content steadily decreases to a final value very similar to the constant value obtained after the first reaction cycle in the reaction at $\mathrm{T}=323.1$ and $\mathrm{P}=15$ bar (see Table 2). This result suggests that the solvolytic process of the Lys-Pd residue (of Ar/Lys-Pd, see above) probably slows down at this smaller temperature. Nevertheless, the extension of the solvolysis is similar to this resulting under more drastic conditions due to the larger reaction times. Moreover, a steady Pd loss, to a final value slightly higher than this obtained at $323.1 \mathrm{~K}$ and 15 bar takes place. The small $\mathrm{P}_{\mathrm{H} 2}$ used in the reaction determines that the $\mathrm{Pd}$ (II) remaining on the surface of the catalysts is slowly but completely reduced to $\operatorname{Pd}(0)$ (see Figure 9).

Thus, the solvolysis of the anchored receptors affects to almost the same amount of molecules when the hydrogenation reaction takes place at milder conditions and at $\mathrm{T}=$ $323.1 \mathrm{~K}$ and $\mathrm{P}_{\mathrm{H} 2}=15$ bar. This fact strongly supports the above hypothesis that the solvolytic process mainly affects the less stable $\mathrm{C}(2)-\mathrm{NH}$ bonds of the molecules adsorbed in narrow micropores. 
Table 4. Data of catalytic activity of Merck/Lys-Pd and Merck/Tren-Pd catalysts at $\mathrm{P}=$ 1.5 barand $\mathrm{T}=303.1 \mathrm{~K}$.

\begin{tabular}{|c|c|c|c|c|c|c|}
\hline Catalyst & Cycle & $\begin{array}{l}\text { Time } \\
\text { (min) }\end{array}$ & $\begin{array}{c}\begin{array}{c}\text { Total } \\
\text { Conversion } \\
(\%)\end{array} \\
\end{array}$ & $\begin{array}{c}\text { Conv. } \\
\text { Octane } \\
(\%)\end{array}$ & $\begin{array}{c}\text { Conv. 2- } \\
\text { octene } \\
(\%) \\
\end{array}$ & TOF $\left(s^{-1}\right)$ \\
\hline \multirow{4}{*}{ Merck/Lys-Pd } & 1 & 240 & 100 & 100 & - & 0.026 \\
\hline & 2 & 240 & 97.84 & 95.38 & 2.46 & 0.025 \\
\hline & 3 & 240 & 99.05 & 95.90 & 3.15 & 0.025 \\
\hline & 4 & 240 & 98.92 & 94.32 & 4.60 & 0.025 \\
\hline \multirow{4}{*}{ Merck/Tren-Pd } & 1 & 270 & 100 & 100 & - & 0.023 \\
\hline & 2 & 270 & 100 & 99.50 & 0.50 & 0.023 \\
\hline & 3 & 270 & 99.39 & 98.39 & 1.61 & 0.023 \\
\hline & 4 & 270 & 99.36 & 98.23 & 1.10 & 0.022 \\
\hline
\end{tabular}

Interestingly, the slowdown of the solvolysis and the Pd loss occurring at the milder reaction conditions have a significant influence in the structure of the Merck/Lys-Pd catalyst as it can be deduced from the $\mathrm{R}$ values in Table 5 . Thus, the $\mathrm{R}$ value increases from 46.9 (for the fresh catalyst) to 51.3 in the first reaction cycle and to 60.6 in the second one, in spite of the $\operatorname{Pd}$ losses and the partial reduction of $\operatorname{Pd}(\mathrm{II})$ to $\operatorname{Pd}(0)$ occurring during the first and second reaction cycles. The increase of the $\mathrm{R}$ values, that points out a rise of the metal centers on the external surface of the catalyst, arises from the slowness of the Pd (II) reduction. This fact allows the migration of the $\operatorname{Pd}(0)$ to the external surface ${ }^{63}$ where it becomes stabilized by the ligand function of the receptor. This migration process is probably the reason which explains that the $\mathrm{R}$ values remain almost constant (Table 5) after the second reaction cycle, in spite of the steady Pd loss. 
Table 5. Analytical data of the catalysts before and after being used in four reaction cycles $(\mathrm{P}=1.5$ bar; $\mathrm{T}=303.1 \mathrm{~K})$ and Factor $\mathrm{R}$ values.

\begin{tabular}{cccccccc}
\hline Catalyst & Cycle & $\mathbf{C}(\%)$ & $\mathbf{H}(\%)$ & $\mathbf{N}(\%)$ & $\mathbf{O}(\%)^{\mathbf{a}}$ & $\mathbf{P d}(\%)$ & R Factor \\
\hline & Fresh & 76.00 & 1.50 & 5.72 & 9.22 & 7.70 & 46.9 \\
\hline Merck/Lys-Pd & 1 & 77.00 & 1.45 & 5.26 & 8.91 & 7.36 & 51.3 \\
& 2 & 79.94 & 1.65 & 4.13 & 7.60 & 6.67 & 60.6 \\
& 3 & 80.23 & 1.24 & 3.97 & 8.31 & 6.24 & 64.7 \\
& 4 & 83.02 & 1.50 & 3.20 & 7.85 & 4.42 & 63.2 \\
\hline \multirow{3}{*}{ Merck/Tren-Pd } & 2 & 82.00 & 1.55 & 4.50 & 7.44 & 4.50 & 89.2 \\
& 1 & 81.02 & 1.05 & 4.95 & 7.88 & 4.91 & 67.1 \\
& 3 & 81.89 & 1.25 & 4.07 & 7.45 & 4.26 & 89.1 \\
& 4 & 83.29 & 2.00 & 2.73 & 7.80 & 4.21 & 89.2 \\
\hline
\end{tabular}

${ }^{\mathrm{a}}$ Obtained as residual; ${ }^{\mathrm{b}}$ Obtained by ICP-MS
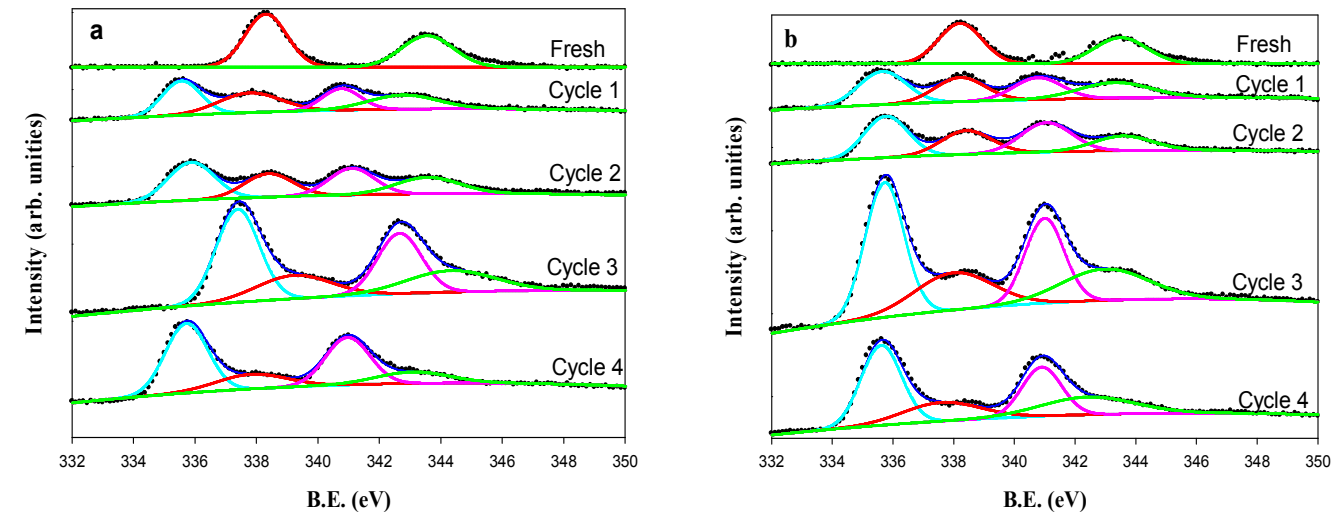

Figure 9. $\mathrm{Pd}_{3 \mathrm{~d} 5 / 2}$ and $\mathrm{Pd}_{3 \mathrm{~d} 3 / 2}$ signals of the XPS spectra of both catalysts fresh and after each reaction cycle (at 303.1 K and 1.5 bar): a) Merck/Lys-Pd catalyst; b) Merck/TrenPd catalyst. 
The activity of Merck/Tren-Pd regarding the conversion to n-octane was similar to this obtained at $323.1 \mathrm{~K}$ and $15 \mathrm{bar}$, i.e. almost $100 \%$ conversion to n-octane in the four reaction cycles (Table 4). Moreover, the required reaction times $(270 \mathrm{~min}$ in the fourth cycles) were twice those needed at $323.1 \mathrm{~K}$ and 15 bar. Similarly to the Merck/Lys-Pd catalyst, the milder reaction conditions slow the solvolysis of the receptor $\mathrm{F}$ residue which is similar to that at $323.1 \mathrm{~K}$ and 15 bar. Nevertheless, in contrast to Merck/Lys$\mathrm{Pd}$, the lixiviation of $\operatorname{Pd}(0)$ only takes place during the first reaction cycle and in much lesser extension (32\%) than when the reaction is carried out at $323.1 \mathrm{~K}$ and 15 bar. Interestingly this value coincides with the molar excess of $\mathrm{Pd}(\mathrm{II})$ that is adsorbed on the Merck surface as $\mathrm{PdCl}_{4}{ }^{2-}$. The $\mathrm{R}$ values of the Merck/Tren-Pd catalyst follow a similar trend that those of Merck/Lys-Pd, i.e. they steadily increase from 52.6 of the fresh catalyst up to 89 after the second reaction cycle and then they remain constant. Thus, similarly to Merck/Lys-Pd under milder reaction conditions (smaller $\mathrm{p}_{\mathrm{H} 2}$ pressure), the $\mathrm{Pd}(\mathrm{II}) \rightarrow \operatorname{Pd}(0)$ process slows down which allows that some $\mathrm{Pd}(0)$ particles formed into inner pores move to the external surface. Nevertheless, the larger binding ability of Tren function to $\mathrm{Pd}$ than this of Lys results in a greater stabilization of $\operatorname{Pd}(0)$ particles in the Merck/Tren-Pd catalyst after the second reaction cycle.

\section{Influence of the functional heterogeneity on the catalytic activity}

The effect of the functional heterogeneity of Merck/Tren-Pd, which contains $\mathrm{Pd}(\mathrm{II})$ adsorbed as $\mathrm{PdCl}_{4}{ }^{2-}$ and as Tren-Pd(II) complexes, on its catalytic efficiency, was investigated. For this purpose, the catalytic behavior of a material of Merck/Tren-Pd type (Merck/Tren-Pd-1/1, see experimental section) containing Tren and $\mathrm{Pd}$ in 1/1 molar relationship ( $0.2 \mathrm{mmol}$ Tren per gram of AC) has been used as catalyst. The material was prepared as described in the experimental section in such a way that the total amount of Tren-Pd complex on the graphitic surface $(0.2 \mathrm{mmol}$ per gram of catalyst) is the optimum one according to the data in the literature for heterogeneous Pd(II)-based catalysts ( $2 \%$ in weight). ${ }^{36-38}$ Four reaction cycles were carried out at $303.1 \mathrm{~K}$ and $\mathrm{P}_{\mathrm{H} 2}=1.5$ bar with the same amounts of solvent, catalyst and reactants as in the case of Merck/Tren-Pd. It is assumed that the whole Pd(II) of Merck/Tren-Pd- $1 / 1$ is as F-Pd(II) complexes. This assumption is based on the triamine function of Tren has much larger binding ability for Pd(II) than the arene centers of AC.

This catalyst showed very high efficiency (100\% conversion to n-octane) and no traces of 2-octene were found in four reaction cycles. Moreover, the reaction times in the four 
reaction cycles $(275 \mathrm{~min}$ ), were very similar to those found in the case of the Merck/Tren-Pd. Thus, the TOF value in the fourth cycles, 0.072, was three time higher than this of Merck/Tren-Pd (0.023). Therefore it is plausible to think that the presence in Merck/Tren-Pd of $\mathrm{PdCl}_{4}{ }^{2-}$ (which are less efficient than F-Pd, as commented above) probably hinder the accessibility of the substrate molecules to the most effective TrenPd centers. This result shows that the control of a suitable functional homogeneity is very important to optimize the efficiency of the catalyst of AC/Ar-S-F-Metal-ion type.

The evolution of the structure of Merck/Tren-Pd-1/1 catalyst during the four reaction cycles is very similar to the described in the previous section for Merck/Tren-Pd. Thus, there is a slow but total reduction of $\mathrm{Pd}(\mathrm{II})$ through the four reaction cycles. Moreover, most of the metal remains stabilized on the surface of the catalysts as $\operatorname{Pd}(0)$ nanoparticles. In addition, a partial solvolysis of Ar-S-F-Pd residues (c.a. $25 \%$ ) and minor Pd lixiviation are produced.

\section{Conclusions}

Several catalysts have been prepared following a new strategy based on the attachment of single mononuclear $\mathrm{Pd}^{2+}$ complexes to a catalytically inert AC. Thus, the catalytic properties of the hybrids so prepared are these of the supported metal complexes. The procedure of preparation consists in the adsorption under mild conditions of two molecular receptors on the graphitic surface of a low functionalized AC (Scheme 2). The particular topology of the receptors allows keeping free a complexing function $\mathrm{F}$ so that the adsorption of $\mathrm{Pd}(\mathrm{II})$ on the AC-receptor hybrid takes place by complexation with this function. The procedure, has two outstanding characteristics: i) the texture and chemical composition of the original AC remain unchanged; ii) it enables the efficient control of the amount of catalytic active sites (the metal centers) and their homogeneous distribution.

High catalytic activity and selectivity of the catalysts in the hydrogenation of 1-octene is found. This behavior is ascribed to the easy accessibility of the reactants to the active sites of the catalysts (the F-Pd ${ }^{2+}$ complexes). The concomitant reduction of the whole $\mathrm{Pd}(\mathrm{II})$ to $\mathrm{Pd}(0)$ is also produced. Moreover, a partial loss of the Pd formed was found which is due to the solvolytic lixiviation of small amounts of S-F-Pd pendant residues of the anchored receptors. Nevertheless, the AC-receptor $\pi-\pi$ interaction is highly stable under the reaction conditions. 
The $\operatorname{Pd}(0)$ nanoparticles resulting in the Merck/Tren-Pd catalyst after the first reaction cycle exhibited high catalytic activity in three additional reaction cycles. This behavior was attributed to the crucial role played by the triamine ligand (F) of Tren in the stabilization of the $\operatorname{Pd}(0)$ nanoparticles. In the case of Merck/Lys-Pd, however, the weaker ligand ability of Lys function to $\operatorname{Pd}(0)$ determines the progressive aggregation of the $\operatorname{Pd}(0)$ nanoparticles giving rise to a steady decrease of catalytic activity. It was also found in this case that the $\operatorname{Pd}(0)$ nanoparticle sizes are not changed through three reaction cycles at milder conditions, i.e. $\mathrm{T}=303.1 \mathrm{~K}$, and $\mathrm{P}_{\mathrm{H} 2}=1.5$ bar. This results in a clear improvement of the catalytic behavior of this material. Moreover this supports that the catalytic activity is controlled by the stability of the bound between the complexing functions and the metal atoms/ions. In addition, it has been shown that, in the catalyst containing the Ar-S-Tren receptor, the suitable control of the surface functional homogeneity is crucial for an efficient control of the catalytic behavior.

The results of this work encourage us to extend the studies on catalysts of the AC/Ar-SF type, to either other reactions and also to the preparation of catalysts based on the adsorption of Ar-S-F receptors on other carbon materials, i.e. graphene (G) and carbon nanotubes (NTs). In the last catalysts the very $\pi-\pi$ stable interaction between Ar-S-F molecules and the $\mathrm{C} \pi$ centers should provide stable catalysts with the advantage (among others) over the case of ACs, that the lack of porosity of $\mathrm{G}$ and NTs provide easier accessibility to the active sites of the catalysts which should provide lower reaction times than in the case of ACs.

\section{Acknowledgements}

The supports of the MINECO (projects MAT2014-60104-C2-1-R, MAT2014-60104C2-2-R and CTM2010-16770), the Autonomous Regional Government (J. de Andalucía, Groups PAIDI FQM273 and RNM342), the Programa de Fortalecimiento de la $\mathrm{I}+\mathrm{D}+\mathrm{I}$ from UGR and Feder funds and the University of Jaén (Project UJA2014/02_FT/06 corresponding to the PROGRAMA OPERATIVO FEDER ANDALUCÍA) are acknowledged.

JUNTA DE ANDALUCIA CONSEJERIA DE ECONOMIA INNOVACION. CIENCIAY BMPLEO

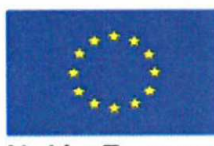

Unión Europea
Andalucia

se mueve con Europa 


\section{References}

1. F. Rodriguez-Reinoso, Carbon, 1998, 36, 159.

2. J. Gonscianska, I. Nowak, P. Nowicki, R. Pietrzak, Chem. Eng. J., 2012, 189-190, 422.

3. W. Xin, Y. Song, RSC Advances, 2015, 5, 83239-83285.

4. L. Li, W. Zhu, Y. Liu, L. Shi, H. Liu, Y. Ni, S. Liu, H. Zhouab, Z.Liu, RSC Advances, 2015, 5, 56304.

5. J. Li, Z. Ren, Y. Ren, L. Zhao, S. Wang, J. Yu, RSC Advances, 2014, 4, 35789.

6. Y. Yan, J. Miao, Z. Yang, F.-X. Xiao, H. B. Yang, B. Liu, Y. Yang, Chem. Soc. Rev., 2015, 44, 3295.

7. J. Mondal, K. T. Nguyen, A. Jana, K. Kurniawan, P. Borah, Y. Zhao, A. Bhaumik, Chem. Commun., 2014, 50, 12095.

8. M. C. Almazán-Almazán, M. Pérez-Mendoza, F. J. López Domingo, M. DomingoGarcía, I. Fernández-Morales, F. J. López-Garzón, Micropor. Mesopor. Mat., 2007, 106, 219.

9. M. C. Almazán-Almazán, M. Pérez-Mendoza, M. Domingo-García, I. FernándezMorales, F. Javier López, F. Javier López-Garzón, Fuel Process. Technol., 2010, 91, 236.

10. W. Feng, P. He, S. Ding, G. Zhang, M. He, F. Dong, J. Wen, L. Du, M. Liu, RSC Adances, 2016, 6, 5949-5956.

11. J. García-Martín, R. López-Garzón, M.L. Godino-Salido, M. D. Gutiérrez-Valero, P. Arranz-Mascarós, R. Cuesta-Martos, F. Carrasco-Marín, Langmuir, 2005, 21, 6908.

12. J. García-Martín, R. López-Garzón, M.L. Godino-Salido, R. Cuesta-Martos, M.D. Gutiérrez-Valero, P. Arranz-Mascarós, Helen Stoeckli-Evans, Eur. J. Inorg. Chem., 2005, 3093.

13. M.D. Gutiérrez-Valero, M.L. Godino-Salido, P. Arranz-Mascarós, R. LópezGarzón, R. Cuesta-Martos, J. García-Martín, Langmuir, 2007, 23, 5995.

14. M. D. Gutiérrez-Valero, P. Arranz-Mascarós, A. Peñas-Sanjuan, M. L. GodinoSalido, R. López-Garzón, A. Santiago-Medina, M. Melguizo-Guijarro, M. Pérez- 
Mendoza, F. J. López-Garzón, M. Domingo-García, Mater. Chem. Phys., 2012, 134, 608 .

15. J. García-Martín, M.L. Godino-Salido, R. López-Garzón, M. D. Gutiérrez-Valero, P. Arranz-Mascarós, H. Stoeckli-Evans. Eur. J. Inorg. Chem., 2008, 1095.

16. M. D. Gutiérrez-Valero, P. Arranz-Mascarós, M. L. Godino-Salido, M. D. LópezLeón, R. López-Garzón, R. Cuesta, Microporous Mesoporous Mater., 2008, 116, 445.

17. M.L. Godino-Salido, R. López-Garzón, P. Arranz-Mascarós, M.D. GutiérrezValero, A. Santiago-Medina, J. García-Martín, Polyhedron, 2009, 28, 3781.

18. K. Karami, N. H. Naeini, V. Eigner, M. Dusek, J. Lipkowski, P. Herves, H. Tavakol, RSC Advances, 2015, 5, 102424.

19. F. Saleem, G. K. Rao, A. Kumar, S. Kumar, M. P. Singh, A. K. Singh, RSC Advances, 2014, 4, 56102.

20. E. L. Fornero, D.L. Chiavassa, A.L. Bonivardi, M.A. Baltanás, Catal. Today, 2011, $172,158$.

21. Y. Wanjin, T. Yang, M. Liuye, C. Ping, L. Hui, Z. Xiaoming, Catal. Commun., $2011, \mathbf{1 3}, 35$.

22. V. Arumugam, W. Kaminsky, N. S. P. Bhuvanesh, D. Nallasamy, RSC Advances, $2015,5,59428$.

23. R. Chinchilla, C. Najera, Chem. Soc. Rev., 2011, 40, 5084-5121.

24. H. Bricout, J.F. Carpentier, A. Montreux, J. Chem. Soc., 1985, 18, 1863.

25. T.P. Voskresenskaya, V.D. Chinakov, V.N. Nkekipelov, A.V. Mshkina, React. Kinet. Catal. Lett., 1986, 32, 359.

26. P. Barbaro, P.S. Pregosin, R. Saltzman, A. Albninati, R.W.Kunz, Organometallics, $1995,14,5160$.

27. S.B. Eremburg, N.V. Bansk, L.N. Mazalov, M.K. Drozdora, V.T. Torgot, J. Struct. Chem., 1995, 36, 941.

28. E.M. Karkova, A.V. Novikova, L.E. Rozantseva, V.M. Frolov, Kinet. Catal. Lett., 1993, 32, 866.

29. D.S.J. Jones and P. R. Pujadó (Eds.), Handbook of Petroleum Processing, Springer, Dordrecht (The Netherlands), 2008. 
30. G.R. List and J.W. King (Eds.), Hydrogenation of Fats and Oils: Theory and Practice, $2^{\text {nd }}$ Ed. AOC Press/Academic Press, Printed in The United States of America, 2010.

31. P. Serp, J.L. Figueiredo (Eds.), Carbon Materials for Catalysis, John Wiley \& Sons, Inc., Hoboken, New Jersey, 2009.

32. V.M. Frolov, D.P. Parenago, A.V. Novikova, L.S. Kovaleva, React. Kinet. Catal. Lett., 1984, 25, 319.

33. G.M. Cherkasin, L.P. Shuikina, D.P. Parenago, V.M. Frolov, Kinet. Catal., 1985, 26, 1110.

34. A. Rakai, D. Tessier, F. Bonzon-Verduraz, New J. Chem., 1992, 16, 869.

35. ${ }^{35}$ P.C. L'Argentière, D.A. Liprandi, E.A. Cagnola, N.S. Fígoli, Catal. Lett., 1997, 44, 101.

36. P.C. L’Argentière, D.A. Liprandi, E.A. Cagnola, M.C. Román-Martínez, C. Salinas-Martínez de Lecea, Appl. Catal. A: Gen., 1998, 172, 41.

37. C. Salinas-Martínez de Lecea, A. Linares-Solano, P.C. L'Argentière, Carbon, 2000, 38, 157.

38. V.B. Vadlokar, G.L. Tembe, M. Ravindranathan, R.N. Ram, H.S. Rama, J. Mol. Catal. A: Chem., 2003, 202, 47.

39. E. Díaz, A.F. Mohedano, L. Calvo, M.A. Gilarranz, J. Casas, J.J. Rodríguez, Chem. Eng. J., 2007, 131, 65.

40. I. Such-Basáñez, M.C. Román-Martínez, C. Salinas-Martínez de Lecea, Carbon, 2004, 42, 1357.

41. J.A. Díaz-Auñón, M.C. Román-Martínez, C. Salinas-Martínez de Lecea, P.C. L’Argentière, E.A. Cagnola, D.A. Liprandi, M.E. Quiroga, J. Mol. Catal. A: Chem., 2000, 153, 243.

42. M. Melguizo, A. Marchal, M. Nogueras, A. Sánchez, J. N. Low, J. Heterocycl. Chem., 2002, 39, 97.

43. C. F. Baes, R. E. Mesmer, The Hydrolysis of Cations, John Wiley and Sons, New York, 1976.

44. M. L. Godino-Salido, R. López-Garzón, M. D. Gutiérrez-Valero, P. ArranzMascarós, M. Melguizo-Guijarro, M. D. López de la Torre, V. Gómez-Serrano, M. Alexandre-Franco, D. Lozano-Castelló, D. Cazorla-Amorós, M. Domingo-García, Mat. Chem. Phys., 2014, 143, 1489. 
45. M. L. Godino-Salido, A. Santiago-Medina, P. Arranz-Mascarós, R. López-Garzón, M. D. Gutiérrez-Valero, M. Melguizo, F.J. López-Garzón. Chem. Eng. Sci., 2014, 114, 94.

46. Peakfit software, 4.12 version, Addlink Software, 2009.

47. P. Arranz, A. Bianchi, R. Cuesta, C. Giorgi, M.L. Godino, M.D. Gutiérrez, R. López, A. Santiago, Inorg. Chem., 2010, 49, 9321.

48. R. López-Garzón, M.L. Godino-Salido, M.D. Gutiérrez-Valero, P. ArranzMascarós, M. Melguizo, C. García, M. Domingo-García, F.J. López-Garzón, Inorg. Chim. Acta, 2014, 417, 208.

49. P. Arranz-Mascaros, C. Bazzicalupi, A. Bianchi, C. Giorgi, M.L. Godino-Salido, M.D. Gutierrez-Valero, R. Lopez-Garzon, and M. Savastano J. Am. Chem. Soc., 2013, 135, 102.

50. Q. Y. Yan and G. Anderegg, Inorg. Chim. Acta, 1985, 105, 121.

51. L. D. Pettit and M. Bezer, Coordination Chemistry Reviews, 1985, 61, 97.

52. L.R. Radovic, C. Moreno-Castilla, J. Rivera-Utrilla, Carbon materials as adsorbents in aqueous solution, in: Radovic, L.R. (Ed.), Chemistry and Physics of Carbon, vol. 27, Marcel Dekker, New York, 2000, pp. 227-405.

53. N. V. Vorob'ev-Desyatovskii, S. A. Kubyshkin, R. I. Ibragimova, V. V. Kaichev, Y. A. Dubrovskii, V. N. Babakov and D. A. Pichugina, Russ. J. Gen. Chem., 2012, 82, 384 .

54. M.C. Román-Martínez, J.A. Díaz-Auñón, P.C. L’Argentière, C. Salinas-Martínez de Lecea, Catal. Lett., 2001, 77.

55. V.F.D. Álvaro, R.A.W. Johnstone, J. Molec. Catal. A: Chem., 2008, $280,131$.

56. C. Liu, Y. Xu, S. Liao, D. Yu, J. Molec. Catal. A: Chem., 1999, 149, 119.

57. B. Siggelkow, M.B. Meder, C.H. Galka, L.H. Gade, Eur. J. Inorg. Chem., 2004, 3424 .

58. J.G. de Vriesby and C.J. Elsevier (Eds.). Handbook of Homogeneous Hydrogenation. Vol. 1. Chapter 4. Wiley-VCH, Weinheim, 2007.

59. A. Corma, H. García, A. Leyva, J. Mol. Catal. A: Chem., 2005, $230,97$.

60. L. M. Rossi, I. M. Nangoi, and N. J. S. Costa, Inorg. Chem. Communications, 2009, 48, 4640 . 
61. P. Arranz-Mascarós, M.D. Gutiérrez-Valero, R. López-Garzón, M.D. López-León, M.L. Godino-Salido, A. Santiago-Medina, H. Stoeckli-Evans, Polyhedron, 2008, 27, 623.

62. R. Cuesta, P. Arranz-Mascarós, J.N. Low, C. Glidewell, Acta Cryst. C, 2001, 57, 918.

63. L.J. Lemus-Yegres, I. Such-Basáñez, M.C. Román-Martínez, C. Salinas-Martínez de Lecea, Appl. Catal., A: General, 2007, 331, 26 


\section{Graphical Abstract}

New hybrid materials based on the grafting of Pd(II)-amino complexes on the graphitic surface of AC: Preparation, structures and catalytic properties

Two novel hybrid catalysts have been prepared by anchoring Pd(II)-amino complexes on the graphitic surface of ACs and their catalytic activities on the 1-octene hydrogenation are presented

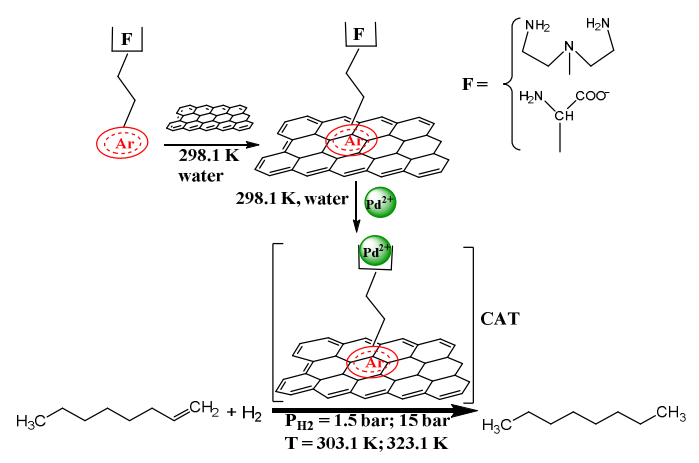

